\title{
Cost-effectiveness analysis in cardiac surgery: A review of its concepts and methodologies
}

\author{
Bart S. Ferket, MD, PhD, ${ }^{\mathrm{a}, \mathrm{b}}$ Jonathan M. Oxman, BA, ${ }^{\mathrm{a}}$ Alexander Iribarne, MD, MS, , , \\ Annetine C. Gelijns, PhD, and Alan J. Moskowitz, MD, FACP ${ }^{\mathrm{a}}$
}

\footnotetext{
From the ${ }^{\mathrm{a} D e p a r t m e n t ~ o f ~ P o p u l a t i o n ~ H e a l t h ~ S c i e n c e ~ a n d ~ P o l i c y, ~ a n d ~}{ }^{\mathrm{b}}$ Institute for Healthcare Delivery Science, Department of Population Health Science and Policy, Icahn School of Medicine at Mount Sinai, New York, NY ${ }^{\mathrm{c}}$ Section of Cardiac Surgery, Dartmouth-Hitchcock Medical Center, Lebanon, NH; and ${ }^{\mathrm{d}}$ The Dartmouth Institute for Health Policy and Clinical Practice, One Medical Center Drive, Lebanon, NH.

This work was supported by a cooperative agreement (U01 HL088942) funded by the National Heart, Lung, and Blood Institute and the National Institute of Neurological Disorders and Stroke of the National Institutes of Health and the Canadian Institutes of Health Research. Drs Ferket, Gelijns, and Moskowitz were supported by the National Center for Advancing Translational Sciences (UL1TR000067). Dr Ferket was supported by American Heart Association Grant \#16MCPRP31030016.

Dr Ferket and Mr Oxman are co-first authors.

Received for publication May 23, 2017; revisions received Oct 31, 2017; accepted for publication Nov 9, 2017; available ahead of print Jan 13, 2018.

Address for reprints: Bart S. Ferket, MD, PhD, Department of Population Health Science and Policy, Icahn School of Medicine at Mount Sinai, One Gustave L. Levy Place, Box 1077, New York, NY 10029 (E-mail: bart. ferket@mountsinai.org).

J Thorac Cardiovasc Surg 2018;155:1671-81

$0022-5223 / \$ 36.00$

Copyright $\odot 2017$ by The American Association for Thoracic Surgery

https://doi.org/10.1016/j.jtcvs.2017.11.018
}

More than 80 million adults in the United States suffer from some form of cardiovascular disease, accounting for close to 1 in 3 US deaths annually and more than $\$ 300$ billion in direct and indirect costs. ${ }^{1}$ Coronary heart disease has been estimated to affect more than $6 \%$ of the US adult population. Moderate-to-severe aortic stenosis (AS) and mitral regurgitation (MR) have been estimated to affect close to $3 \%$ and $9 \%$ of US adults ages 75 and older, respectively. ${ }^{1,2}$ Atrial fibrillation (AF) and heart failure (HF) each affect up to 6 million Americans. ${ }^{1}$ The development of new and improved technologies, including minimally invasive and hybrid revascularization procedures, transcatheter aortic valve replacement, MitraClip (Abbott Laboratories, Abbott Park, Ill), continuous-flow left ventricular assist devices (LVADs), and ablation devices for $\mathrm{AF}$, has greatly changed our approach to these conditions and expanded indications for treatment.

With increasing health care expenditures, ${ }^{4}$ and a health policy environment promoting greater efficiency and value-based care, ${ }^{5}$ the relevance of evaluating costeffectiveness in cardiac surgery has become more critical. The growing focus on cost-effectiveness research in cardiac surgery can be shown by an increasing number of publications in the field (Figure 1). Although a portion of this trend may be the result of the aforementioned health care system factors, the continuously changing surgical landscape with approval of new devices has also been an enabler of cost-effectiveness analysis (CEA) in cardiac surgery. For example, there has been a steady increase in the number of CEA publications that have focused on the treatment of AS and MR since 2011, and almost all have evaluated new

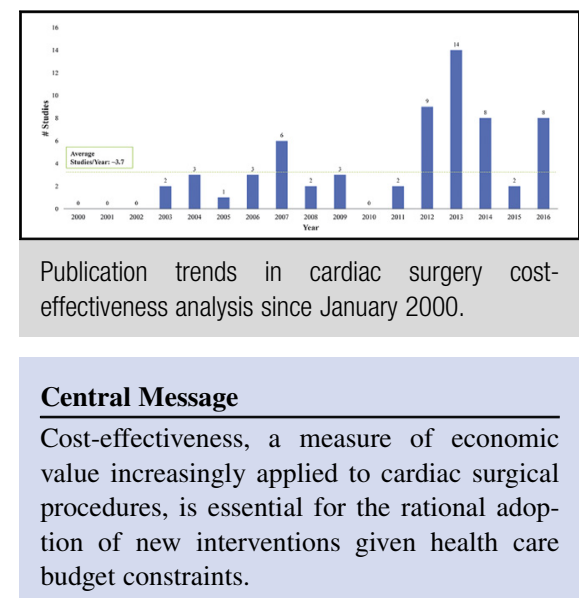

Perspective

Cost-effectiveness analysis in cardiac surgery continues to grow in relevance, with an increasing emphasis on value-based care and the expansion of high-cost devices and procedures. Economic data are increasingly being gathered within clinical trials and in cardiac surgery registries, providing opportunities to integrate economic outcomes into an evolving surgical practice.

See Editorial Commentaries pages 1682 and 1684.

procedures such as transcatheter aortic valve replacement and MitraClip (Figure 1). Although other countries have adopted CEAs into their budgetary considerations, US federal payers have not explicitly used CEA to establish guidelines, and costs have only been considered implicitly. ${ }^{4,6-8}$ However, more recently, the American College of Cardiology/American Heart Association has recommended the inclusion of CEA in their clinical guidelines, whereas other public and private sector organizations have also incorporated value-based measures in their analyses. ${ }^{4,7,9,10}$

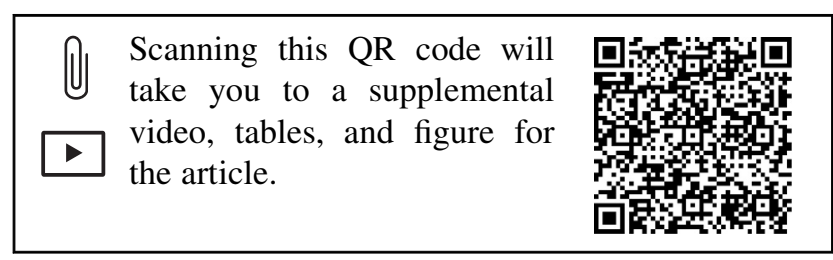


Clinicians, as well as payers, are critical for effectively and efficiently allocating society's health care resources and maximizing value through evidence-based decisions. Although health care economics education has been increasingly incorporated into the standard medical school curriculum for physicians in training, it may not be sufficient. ${ }^{4,11,12}$ As such, this paper was written as a primer on the theory and application of CEA for cardiac surgeons. We additionally summarized the findings from recent CEAs on 5 cardiac conditions: coronary artery disease, AS, MR, AF, and end-stage HF, with a focus on the latter to illustrate the use of CEA for guiding surgical decisionmaking.

\section{METHODS}

We developed a PubMed search for CEAs published since January 2000 and in the English language that evaluated cardiac surgical interventions for management of these 5 cardiac conditions. Search terms included combinations of Medical Subject Headings terms and key word variations for coronary artery bypass graft, aortic valve replacement, mitral valve surgery, surgical ablation, maze, LVAD, and the applicable cardiac conditions. To capture CEAs, Medical Subject Headings terms and variations of "cost-effectiveness analysis" and "quality-adjusted life years" were combined with the aforementioned search terms.

Articles were selected based on a review of titles and abstracts followed by a text review. We only included analyses with both cost and effectiveness components. The effectiveness component was limited to quality-adjusted life years (QALYs) or life-years. We selected 63 articles in which the analysis included at least 1 cardiac surgical intervention (Figure E1).

We extracted all of the relevant information from the CEAs and developed matrices, grouped by the 5 conditions. For each matrix, we delineated the target population, setting and location, comparisons made, time horizon, and base case measures of cost-effectiveness. Table $1^{13-25}$ depicts the matrix for end-stage HF, and Tables E1-E4 depict the matrices for the 4 other conditions.

\section{COST-EFFECTIVENESS ANALYSIS}

Within a formal CEA, the average costs, in currency units, and health outcomes of the relevant competing medical options can be compared for a particular patient, eg, the "average" or typical patient, or a heterogeneous population. Health outcome (the measure of effectiveness) is preferably expressed as life expectancy adjusted for time spent at less than full quality, ie, "quality-adjusted life expectancy," typically measured in QALYs (Figure 2). Generally, CEAs are pragmatic in that they evaluate and compare the effects of medical options on costs and health outcomes in the setting of usual clinical practice. Although many of the CEAs we identified compared just 2 treatment options, in instances in which there are greater than 2 relevant treatment options, all should be considered in the analysis.

Once the average cost and effectiveness of all of the relevant alternative options are measured, one can then order them by cost, from lowest to highest. Any option that costs the same or more than a competing option but is less effective is clearly less desirable and should be rejected from further consideration. Such options are said to be dominated. The options that remain, ie, those that are not eliminated due to dominance, are now in order of both increasing costs and increasing effectiveness and can be compared 2 at a time to determine whether the added cost of the more expensive and more effective option in the pair meets our expectation of good value. The metric used for estimating value is the incremental

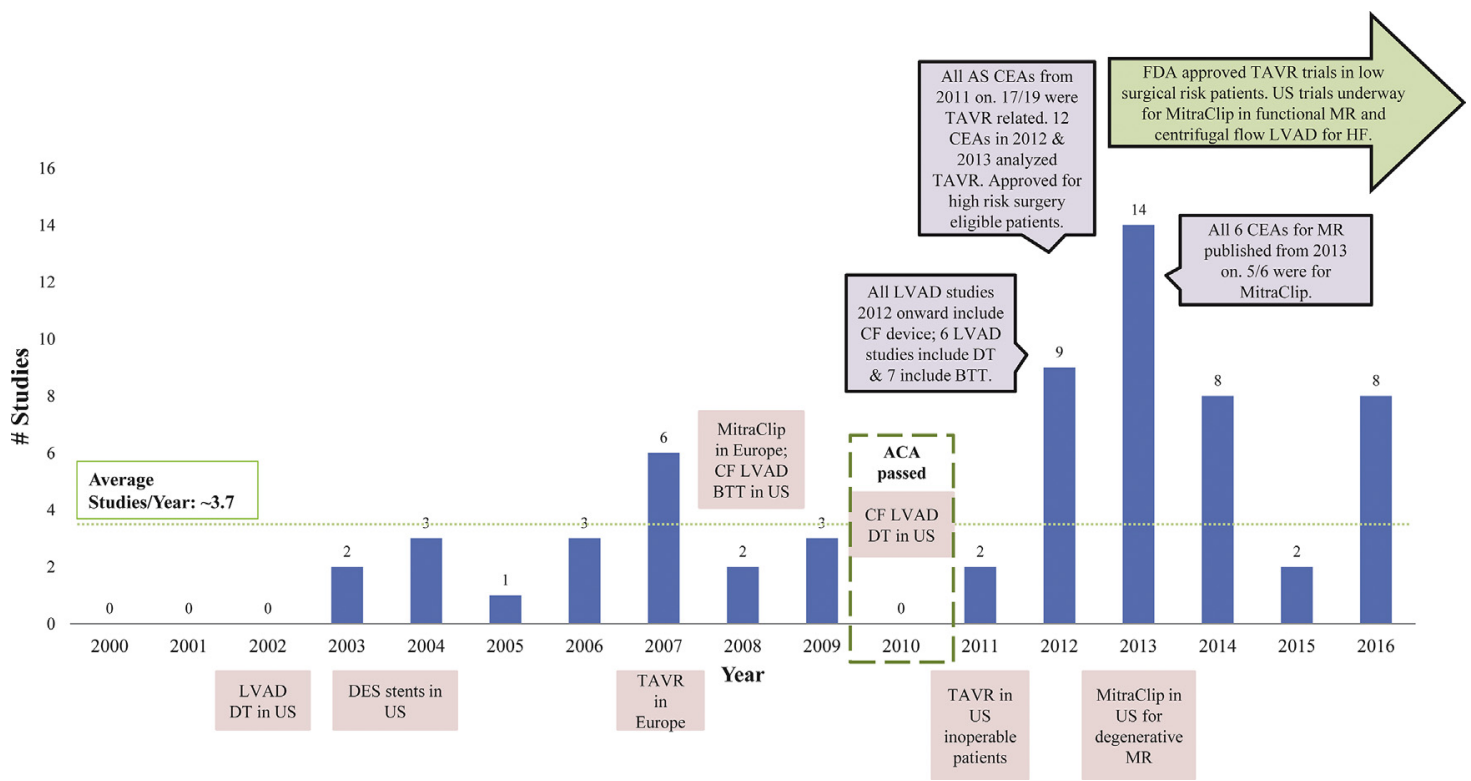

FIGURE 1. Cost-effectiveness analyses in cardiac surgery published since January 2000. LVAD, Left ventricular assist device; $D T$, destination therapy; $D E S$, drug-eluting stent; TAVR, transcatheter aortic valve replacement; $C F$, continuous-flow; $B T T$, bridge to transplant; $A C A$, Affordable Care Act; $A S$, aortic stenosis; $C E A$, cost-effectiveness analysis; $F D A$, Food and Drug Administration; $M R$, mitral regurgitation; $H F$, heart failure. 
TABLE 1. Summary of cost-effectiveness analysis findings for end-stage heart failure

\begin{tabular}{|c|c|c|c|c|c|c|c|c|}
\hline Author & Year & Comparison & Country & Horizon & $\begin{array}{l}\text { Cost } \\
\text { year }\end{array}$ & $\Delta$ Costs & $\Delta$ Effectiveness $*$ & ICER* \\
\hline \multicolumn{9}{|c|}{ LVAD destination therapy } \\
\hline $\begin{array}{l}\text { Samson and } \\
\text { colleagues }^{13}\end{array}$ & 2004 & $\begin{array}{l}\text { Pulsatile LVAD } \\
\text { vs MM }\end{array}$ & USA & Lifetime & 2002 & $\$ 338,882$ & 0.42 & $\$ 802,700$ \\
\hline $\begin{array}{l}\text { Clegg and } \\
\text { colleagues }^{14}\end{array}$ & 2007 & $\begin{array}{l}\text { Pulsatile LVAD } \\
\text { vs MM }\end{array}$ & $\begin{array}{l}\text { United } \\
\text { Kingdom }\end{array}$ & $5 \mathrm{y}$ & 2003 & $£ 101,998$ & 0.59 & $£ 170,616$ \\
\hline $\begin{array}{l}\text { Rogers and } \\
\text { colleagues }^{15}\end{array}$ & 2012 & CF LVAD vs MM & USA & $5 \mathrm{y}$ & 2009 & $\$ 297,551$ & 1.5 & $\$ 198,184$ \\
\hline $\begin{array}{l}\text { Neyt and } \\
\quad \text { colleagues }^{16}\end{array}$ & 2013 & CF LVAD vs MM & Dutch & Lifetime & 2010 & $€ 299,100$ & 2.83 & $€ 107,600$ \\
\hline $\begin{array}{l}\text { Long and } \\
\text { colleagues }^{17}\end{array}$ & 2014 & CF LVAD vs MM & USA & Lifetime & 2012 & $\$ 480,400$ & 2.38 & $\$ 201,600$ \\
\hline $\begin{array}{l}\text { Baras } \\
\text { Shreibati and } \\
\text { colleagues }^{18}\end{array}$ & 2016 & LVAD vs MM & USA & Lifetime & 2016 & $\$ 364,400$ & 1.74 & $\$ 209,400$ \\
\hline \multicolumn{9}{|l|}{$\begin{array}{l}\text { LVAD bridge-to- } \\
\text { transplant }\end{array}$} \\
\hline $\begin{array}{l}\text { Clegg and } \\
\text { colleagues }^{19}\end{array}$ & 2006 & $\begin{array}{l}\text { Pulsatile LVAD } \\
\text { vs MM }\end{array}$ & $\begin{array}{l}\text { United } \\
\text { Kingdom }\end{array}$ & $5 \mathrm{y}$ & 2003 & $£ 99,475$ & 1.53 & $£ 65,242$ \\
\hline $\begin{array}{l}\text { Sharples and } \\
\text { colleagues }^{20}\end{array}$ & 2006 & $\begin{array}{l}\text { CF/pulsatile } \\
\text { LVAD vs MM }\end{array}$ & $\begin{array}{l}\text { United } \\
\text { Kingdom }\end{array}$ & Lifetime & $2004 / 05$ & $£ 42,936$ & -1.72 & $\begin{array}{l}\text { LVAD } \\
\text { dominated } \\
\text { by MM }\end{array}$ \\
\hline $\begin{array}{l}\text { Moreno and } \\
\text { colleagues }^{21}\end{array}$ & 2012 & CF LVAD vs MM & $\begin{array}{l}\text { United } \\
\text { Kingdom }\end{array}$ & Lifetime & 2011 & $£ 142,495$ & 0.55 & $£ 258,922$ \\
\hline \multirow[t]{3}{*}{$\begin{array}{l}\text { Alba and } \\
\text { colleagues }^{22}\end{array}$} & 2013 & CF LVAD vs MM $\dagger$ & Canada & $20 y$ & 2011 & $\$ 100,841$ & $1.19(\mathrm{LY})$ & $\$ 84,964(/ \mathrm{LY})$ \\
\hline & & CF LVAD vs MM $\dagger$ & Canada & $20 \mathrm{y}$ & 2011 & $\$ 112,779$ & $1.14(\mathrm{LY})$ & $\$ 99,039(/ \mathrm{LY})$ \\
\hline & & CF LVAD vs MM $\dagger$ & Canada & $20 \mathrm{y}$ & 2011 & $\$ 144,334$ & $1.21(\mathrm{LY})$ & $\$ 119,574$ (/LY) \\
\hline \multirow[t]{2}{*}{$\begin{array}{l}\text { Sutcliffe and } \\
\text { colleagues }^{23}\end{array}$} & 2013 & CF LVAD vs MM & $\begin{array}{l}\text { United } \\
\text { Kingdom }\end{array}$ & Lifetime & 2010 & $£ 135,726$ & 2.46 & $£ 55,173$ \\
\hline & & $\begin{array}{l}\text { CF LVAD ATT vs } \\
\text { CF LVAD }\end{array}$ & $\begin{array}{l}\text { United } \\
\text { Kingdom }\end{array}$ & Lifetime & 2010 & $-£ 32,813$ & -1.59 & $£ 20,637$ \\
\hline $\begin{array}{l}\text { Clarke and } \\
\text { colleagues }^{24}\end{array}$ & 2014 & CF LVAD vs MM & $\begin{array}{l}\text { United } \\
\text { Kingdom }\end{array}$ & Lifetime & 2011 & $£ 127,391$ & 2.38 & $£ 53,527$ \\
\hline $\begin{array}{l}\text { Pulikottil- } \\
\text { Jacob and } \\
\text { colleagues }^{25}\end{array}$ & 2014 & $\begin{array}{l}\text { HeartWare CF LVAD } \\
\text { vs HeartMate II } \\
\text { CF LVAD }\end{array}$ & $\begin{array}{l}\text { United } \\
\quad \text { Kingdom }\end{array}$ & Lifetime & 2011 & $£ 27,042$ & 1.14 & $£ 23,530$ \\
\hline $\begin{array}{l}\text { Long and } \\
\text { colleagues }^{17}\end{array}$ & 2014 & $\begin{array}{l}\text { CF LVAD vs MM vs } \\
\text { no transplant }\end{array}$ & USA & Lifetime & 2012 & $\begin{array}{l}\text { CF LVAD } \\
\text { vs MM: } \\
\$ 482,900 ; \\
\text { MM vs no } \\
\text { transplant: } \\
\$ 398,700\end{array}$ & $\begin{array}{l}\text { CF LVAD } \\
\text { vs MM: } \\
2.13 ; \mathrm{MM} \\
\text { vs no } \\
\text { transplant: } \\
4.12\end{array}$ & $\begin{array}{l}\text { CF LVAD } \\
\text { vs MM: } \\
\$ 226,300 ; \\
\text { MM vs no } \\
\text { transplant: } \\
\$ 96,900\end{array}$ \\
\hline
\end{tabular}

ICER, Incremental cost-effectiveness ratio; $L V A D$, left-ventricular assist device; $M M$, medical management; $C F$, continuous-flow; $L Y$, life-years; $A T T$, alternative to transplant $* \triangle$ Effectiveness and ICERs were calculated using QALYs unless specified to be LY. †High, medium, and low risk from top to bottom.

cost-effectiveness ratio (ICER), which is measured in costs per additional unit of health gained, and is calculated as the difference in average costs of the 2 options under consideration divided by the difference in their average effectiveness, ie, $\frac{\overline{\operatorname{Costs}_{1}}-\overline{\overline{\operatorname{Costs}_{2}}}}{\overline{Q A L Y s_{1}}-\overline{Q A L Y s_{2}}}$. After further eliminating less efficient ("extendedly dominated") options, costeffectiveness is then assessed in pairs for all remaining options by comparing the ICER for each pair with a cost-effectiveness threshold value, ie, the presumed maximum dollar amount that society would be willing to pay for a gain in a unit of health. For the United States, there is currently no single agreed-on cost-effectiveness threshold, but measures in the range of $\$ 50,000$ to $\$ 200,000$ per QALY have been used and recommended. ${ }^{4}$ Conclusions from a CEA about implementing interventions 


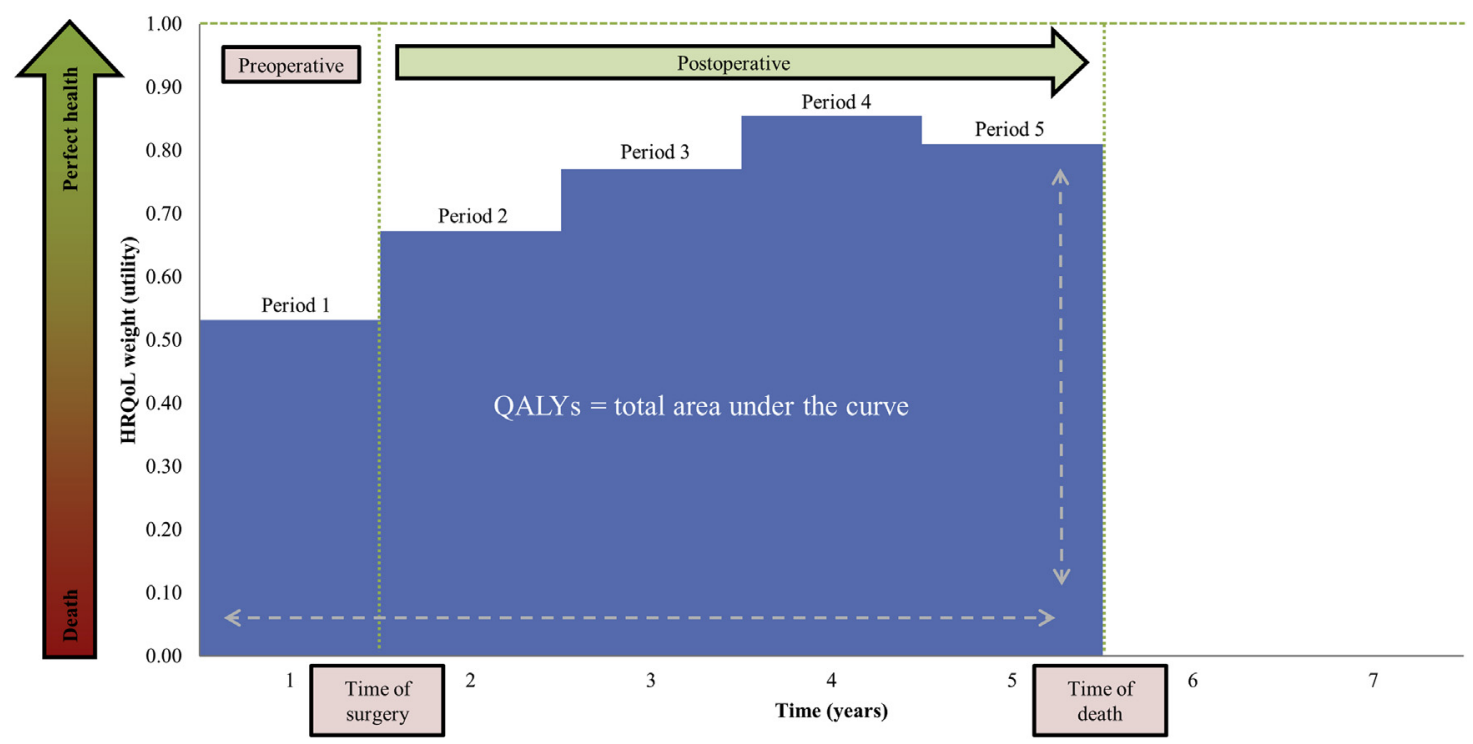

FIGURE 2. Hypothetical individual patient's follow-up duration adjusted for quality of life. The patient's health state is longitudinally measured via a health state classification instrument at preoperative and several postoperative time points. The health states are then converted into utilities using HRQoL weights based on societal preferences. QALYs are represented by the area under the curve, ie, the sum of each period multiplied by the HRQoL/utility during that period. Zero indicates death, whereas 1 indicates perfect health. $H R Q o L$, Health-related quality-of-life; $Q A L Y$, quality-adjusted life year.

are based on the mean cost and QALY estimates, irrespective of their uncertainty. Uncertainty around the estimates is more relevant to deciding whether further research is required. Table 2 and Video 1 illustrate these principles comparing 3 treatment options for patients with end-stage HF (medical management, axial-flow LVAD, and centrifugal-flow LVAD).

\section{ESTIMATION OF COSTS}

A key component of CEA is calculating the average cost of each alternative intervention. Typically, CEAs are conducted from a health care or societal perspective. CEAs from a health care perspective should capture current and future formal health care costs, including those incurred by third-party payers and patients' out-of-pocket expenses. ${ }^{8}$ Formal health care costs include those directly and indirectly related to the disease or its management. ${ }^{8,26,27}$ Typically, for surgical interventions, it includes costs related to the index procedure, additional hospitalizations, physician fees, and other costs, such as rehabilitation facilities, nursing homes, and outpatient care.

When a societal perspective is chosen, informal health care costs, including those associated with patients' time, care from family members or others that were not reimbursed, and transportation should be incorporated, in addition to formal health care costs. Non-health care costs, such as those associated with lost productivity, nonmedical consumption, and other impacted items, may also be included. $8,26,28$

Medical resource use and its associated costs can be gathered prospectively in the setting of randomized controlled trials (RCTs), observational studies, or taken from multiple secondary sources. Total costs are often not captured directly but rather approximated by multiplying resource use (eg, medical personnel hours) by unit costs or by applying Centers for Medicare \& Medicaid Services-established relative price weights, such as those derived from Diagnostic-Related Groups and fee schedules. ${ }^{27,29-31}$ Because such prospective payments are based on average resource use, this leads to loss of cost variability and precision across patients. ${ }^{30-33}$ In some instances, patient-level claims data are used, which capture both resource use and associated charges ${ }^{26-29,34}$; however, such charges need to be converted to costs (ie, the actual value of the resources consumed), which can be accomplished by the use of institution-specific cost-tocharge ratios (obtainable from Centers for Medicare \& Medicaid Services hospital cost reports). ${ }^{26-29,34-36}$

When charges are available at a cost center or department level (eg, from uniform billing forms), departmental level cost-to-charge ratios can be used. ${ }^{30,31,37-39}$ However, when only total hospitalization charges are available, hospital-level aggregated cost-to-charge ratios may be used. There are times when resource use and costs are not gathered at all and expected costs derived from similar studies may be used as a proxy, conditional on the occurrence of clinical outcomes. ${ }^{8,26,28,29}$ An example of some of these methods can be found in a CEA comparing long-term continuous-flow LVAD therapy to medical management, which used hospital claims for patients with an LVAD enrolled in a RCT to estimate procedure costs, Medicare claims data to estimate physician fees, 
TABLE 2. Hypothetical examples of CEAs comparing centrifugal continuous-flow LVAD versus axial continuous-flow LVAD versus medical management

\begin{tabular}{|c|c|c|c|c|}
\hline Scenarios* & Costs $(\$)$ & QALYs & ICER $(\$ / Q A L Y)$ & Comparison \\
\hline \multicolumn{5}{|l|}{ Scenario 1: Dominance } \\
\hline Medical management & 53,000 & 0.41 & N/A & N/A \\
\hline Centrifugal LVAD & 390,000 & 1.92 & 223,179 & Centrifugal LVAD vs medical management \\
\hline Axial LVAD & 416,000 & 1.88 & Dominated by centrifugal LVAD & Axial LVAD vs centrifugal LVAD \\
\hline \multicolumn{5}{|c|}{ Scenario 2: Extended dominance } \\
\hline Medical management & 53,000 & 0.41 & N/A & N/A \\
\hline Axial LVAD & 392,000 & 1.91 & $(226,000)$ Extended dominance & Axial LVAD vs medical management \\
\hline Centrifugal LVAD & 406,000 & 1.99 & $(175,000)$ & Centrifugal LVAD vs axial LVAD \\
\hline & & & 223,418 & Centrifugal LVAD vs medical management \\
\hline \multicolumn{5}{|c|}{ Scenario 3: 1 ICER found to be below cost-effectiveness threshold of \$200,000/QALY } \\
\hline Medical management & 53,000 & 0.41 & N/A & N/A \\
\hline Centrifugal LVAD & 252,000 & 2.01 & 124,375 & Centrifugal LVAD vs medical management \\
\hline Axial LVAD & 392,000 & 1.91 & Dominated by centrifugal LVAD & Axial LVAD vs centrifugal LVAD \\
\hline \multicolumn{5}{|c|}{ Scenario 4: 2 ICERs found to be below cost-effectiveness threshold of $\$ 200,000 / \mathrm{QALY}$} \\
\hline Medical management & 53,000 & 0.33 & N/A & N/A \\
\hline Axial LVAD & 301,000 & 2.33 & 124,000 & Axial LVAD vs medical management \\
\hline Centrifugal LVAD & 352,100 & 2.7 & 137,838 & Centrifugal LVAD vs axial LVAD \\
\hline
\end{tabular}

In scenario 1, axial LVAD is dominated by centrifugal LVAD because, on average, it both costs more and is the least effective of the 2. Therefore, it should be eliminated from further consideration. The ICER that compares the 2 remaining treatment options (centrifugal LVAD and medical management) is $\$ 223,379$, which is above the proposed cost-effectiveness threshold of $\$ 200,000 / \mathrm{QALY}$. Consequently, in this scenario, medical management is the most cost-effective option for treating advanced heart failure. Scenario 2 illustrates the concept of extended dominance. Centrifugal LVAD both costs more and is more effective than the axial flow LVAD option. However, what we observe here is that the cost per each additional unit of health gained by centrifugal flow LVAD therapy over axial flow LVAD therapy $(\$ 175,000)$ is less than the cost for each additional unit of health gained with axial flow LVAD over medical management $(\$ 226,000)$. It follows that centrifugal flow LVAD will generate health at a rate cheaper than axial flow therapy $(\$ 223,418)$ and therefore should be the preferred option. So, by "extended dominance," axial flow therapy is eliminated. However, because the ICER for centrifugal therapy compared to medical therapy is over the $\$ 200,000 /$ QALY threshold, medical management is likely the most cost-effective option for treating advanced heart failure in this scenario. In scenario 3, axial LVAD is dominated by centrifugal LVAD and the ICER for centrifugal LVAD versus medical management is below the cost-effectiveness threshold, indicating centrifugal LVAD is the best option. In scenario 4, although both ICERs lie below the cost-effectiveness threshold, centrifugal LVAD offers the greatest overall health benefit and is considered the most attractive option here. $Q A L Y$, Quality-adjusted life year; ICER, incremental cost-effectiveness ratio; N/A, not available; $L V A D$, left ventricular assist device. *The values provided have been loosely adapted from actual studies and serve as illustrations.

Diagnostic-Related Group-based Medicare reimbursement rates to estimate re-hospitalization costs, and a study of bridge-to-transplant (BTT) patients with an LVAD as the source for estimates of outpatient costs. ${ }^{15}$

\section{ESTIMATION OF EFFECTIVENESS}

Formal CEAs integrate a valuation of health with survival to generate a composite measure of effectiveness, quality-adjusted life expectancy, for each intervention being compared. Analyzing unadjusted life expectancy as well helps to demonstrate the extent to which analytical results are influenced by nonfatal versus fatal events. ${ }^{15,16,40-44}$ Health states can be measured longitudinally by periodically administering health status instruments to patients, eg, before and after an intervention. Commonly used generic, health-related quality-of-life (HRQoL) indexes, which are also suitable for use in cardiac surgery patients, include the EuroQoL, Health Utilities Index, SF-36, and SF-12. ${ }^{28,29,45,46}$

For CEAs conducted from a societal or health care perspective, patient responses to these generic HRQoL indexes can then be valued according to community preferences determined by a sample of the general population. ${ }^{8,28,29,47}$ Applying such community preference weights to health states transforms them into a utility score, with greater values indicating greater well-being. ${ }^{28,29,47}$ On a utility scale, the best-possible health state, ie, full health, is assigned a value of 1 , whereas death is assigned a value of 0 . Some instruments, however, depict health states perceived as being worse than death by utility scores below 0 .

For a given individual, quality-adjusted life expectancy is calculated by multiplying the duration of each time

\section{Cost-Effectiveness Analysis in Cardiac Surgery: a Review of Its Concepts and Methodologies}

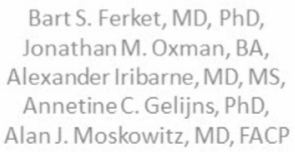

VIDEO 1. Key concepts and methodologies of cost-effectiveness analysis in cardiac surgery. Video available at: http://www.jtcvsonline.org/article/ S0022-5223(17)32690-9/fulltext. 
period with a consistent quality of life (QoL) by the associated QoL preference measure (ie, utility score) and then summing all utility-weighted periods over the entire time horizon (Figure 2). ${ }^{4,28,29}$ For example, a life expectancy of 10 years at a utility preference weight of 0.5 is equivalent to 5 years lived at a full health (utility preference weight of one). Typically, quality-adjusted life expectancy is expressed in QALYs. When comparing average quality-adjusted life expectancy for alternative interventions, one calculates the difference in the "shaded" area of Figure 2 across all patients per intervention.

Sometimes HRQoL metrics may not have been collected in the course of a study. In that case, one would need to use proxy values derived from the literature for the utility weighting of health states. For example, the previously mentioned CEA on continuous-flow LVADs derived the needed HRQoL adjustments from published reports, dependent on New York Heart Association class, rather than measuring them directly in the patients who were under study. ${ }^{15}$

\section{STUDY DESIGN AND CONSIDERATIONS}

Understanding the findings of a CEA requires knowledge of the quality of the data sources, of its perspective (eg, societal or payer), of its time horizon, and whether outcomes were modeled or measured. For model-based CEAs, model type, parameter assumptions, and model validity are important considerations.

CEAs may just use data from an RCT, referred to as within-trial CEAs, but will often develop a decision model that integrates various data types (survival, morbidity, costs, and QoL). Different decision modeling methods exist, but the most frequently used technique is statetransition modeling (eg, Markov) based on predefined health states, rates of mortality, and other events. ${ }^{28,48,49}$ For example, in a CEA that used a Markov model that compared percutaneous coronary intervention stenting with minimally invasive coronary artery bypass graft for left anterior descending artery disease, probabilities for repeat revascularizations and adverse events were derived from a meta-analysis and other literature sources. ${ }^{50}$

CEAs may derive results based solely on the observed period for which patient data were collected or may report conclusions based on extrapolated future outcomes. Although projections beyond the observed data require assumptions, strict within-trial data may be too short-term to provide a meaningful estimate of costeffectiveness. For example, a CEA of ablation surgery for AF that used 1-year within-trial data only found that concomitant ablation was too costly because of longer operation time and catheter ablations costs, ie, the full benefits of performing this procedure were not adequately captured during the relatively short study follow-up period. $^{51}$ However, another analysis, which used a decision model that projected 15-year outcomes by assigning probabilities to adverse events and survival beyond the period of time for which there were empirical data, was able to demonstrate ablation's cost-effectiveness. ${ }^{52}$ When CEAs evaluate outcomes over an extended time horizon covering multiple years, they should also adjust for time preference, ie, the fact that individuals typically value years of life experienced in the nearer future more dearly than those experienced later in life. This is analogous to how we value dollars we can spend now more than an equivalent amount we could spend in the future. Typically, both future costs and health outcomes are adjusted downward by using a discount rate (recommended at $3 \%$ for the United States). ${ }^{8,28,29}$

To increase the credibility of the model's predictions, model performance should be evaluated. With external validation, model predictions, such as survival, are compared with independently measured data from another trial or observational studies.

\section{UNCERTAINTY AND SENSITIVITY ANALYSIS}

Uncertainty analysis is conducted to quantify the impact that a range of plausible cost and effectiveness input values could have on the model's outcomes and related recommendations. When CEA results are uncertain, one may want to recommend further research to obtain more information. A relevant source of uncertainty in CEA are the parameter estimates, ie, uncertainty related to clinical event rates, utility scores, costs and other model inputs. Such uncertainty arises from the size and variability of the study from which the data was derived and the validity and generalizability of that study. Therefore, rather than only using input values based on averages, CEAs ideally use a range of plausible input values that give rise to different cost-effectiveness outcomes. ${ }^{28,53}$

Calculating a range of outcomes due to parameter uncertainty is performed through "probabilistic" or "deterministic sensitivity analysis." In model-based CEAs with probabilistic sensitivity analysis (PSA), different combinations of all input values are randomly selected from a priori-defined parameter distributions and for each set of parameter values, the model is run to produce a distribution of cost-effectiveness outcomes. When using patient-level data (eg, in within-trial CEAs), bootstrapping can be performed without prespecifying input distributions. Results from PSA can be summarized as $95 \%$ confidence intervals around cost and effectiveness outcomes or as the percent of bootstrap iterations in which a particular intervention is the most cost-effective option given a chosen cost-effectiveness threshold (Figures 3 and 4). ${ }^{28,53}$ One British CEA showed that greater cost-effectiveness thresholds increased the probability of BTT-LVAD's 


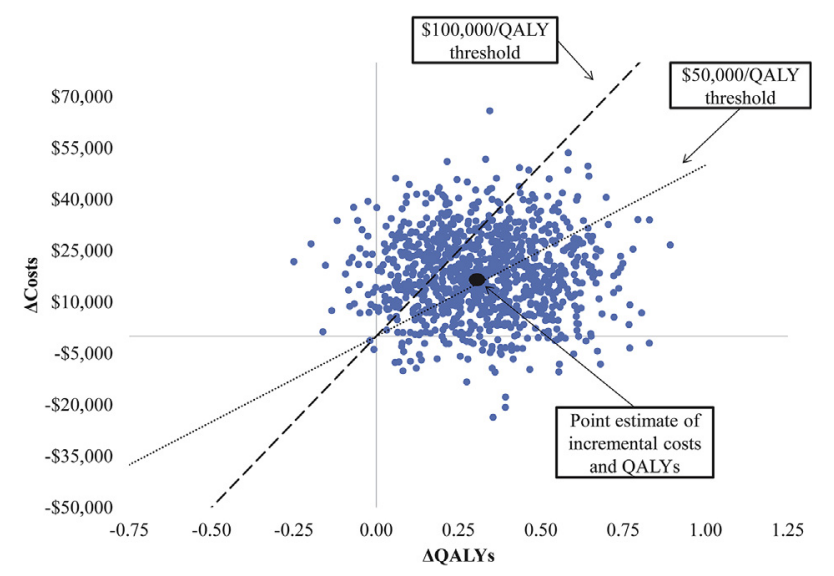

FIGURE 3. Hypothetical PSA plotted on a cost-effectiveness plane. When 2 competing surgeries are compared, surgery $A$ versus $B$, a scatterplot of the difference in average costs and QALYs per PSA iteration can be created with a diagonal representing the cost-effectiveness threshold. The percentage of points lying to the right of a given threshold line indicates the probability that the intervention is cost-effective relative to the competing intervention. Multiple cost-effectiveness thresholds can be plotted to determine the impact on the probability of cost-effectiveness. The lower right quadrant represents iterations in which the intervention $A$ is "dominant" due to having lower incremental costs and greater incremental QALYs than B. The upper left quadrant represents iterations where A is "dominated" due to greater incremental costs and lower incremental QALYs. The upper right and lower left quadrants represent tradeoffs between greater and lower incremental costs and QALYs, respectively. $Q A L Y$, Quality-adjusted life year.

cost-effectiveness, eg, given a cost-effectiveness threshold of $£ 50,000 / \mathrm{QALY}, \mathrm{BTT}-\mathrm{LVAD}$ would be economically attractive in $41 \%$ of the PSA iterations. ${ }^{24}$ In deterministic sensitivity analysis, individual parameter values are varied by the researcher within a realistic range to test how they impact outcomes (Figure 5). ${ }^{28,53}$

\section{COST-EFFECTIVENESS OF LVAD THERAPY FOR END-STAGE HF}

To illustrate the value of CEA, we reviewed the CEA literature on LVAD therapy for end-stage HF. Thirteen CEAs were identified by our literature search, of which 6 studies compared LVAD as destination therapy (DT) with medical management in heart transplant-ineligible patients, ${ }^{13-18} 7$ studies compared BTT-LVAD with medical management in transplant-eligible patients,,${ }^{17,19-24}$ and 1 study compared second- with third-generation BTT-LVADs (Table 1). ${ }^{25}$

For DT, all generations of LVADs were consistently more costly than medical management, mainly as the result of the high upfront implantation costs and costs associated with rehospitalizations. However, all studies found that LVADs improved survival and QoL. CEAs conducted for the US health care system demonstrated a substantial improvement in the ICER over time, which can be mainly attributed to

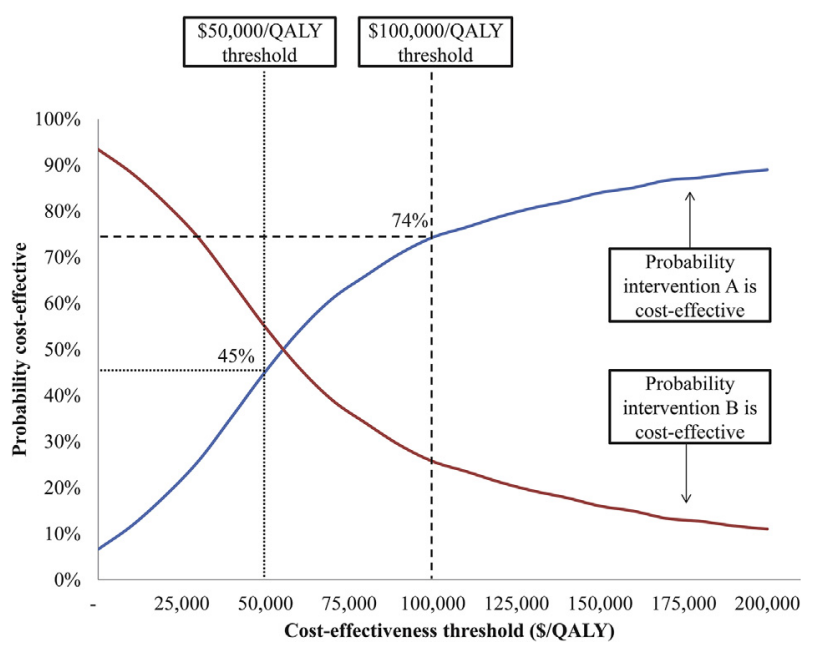

FIGURE 4. Cost-effectiveness acceptability curves. This graph shows the probability of each intervention being cost-effective given a range for society's willingness to pay to gain 1 QALY. As the cost-effectiveness threshold increases, the probability that surgery $A$ is cost-effective increases while that of $B$ decreases (equal to $100 \%$ - probability $A$ is cost-effective). The vertical lines represent just 2 of the cost-effectiveness thresholds and correspond directly to the diagonals on the cost-effectiveness plane. $Q A L Y$, Quality-adjusted life year.

improved survival, reduced implantation costs, improved patient selection, and reduced device complications observed with newer-generation LVADs. ${ }^{13,15,17,18}$ The effectiveness of LVAD increased by 0.42-0.59 QALY with pulsatile and 1.5-2.83 QALYs with continuous-flow device technology. A direct comparison of cost estimates among CEAs on DT-LVAD versus medical management remains

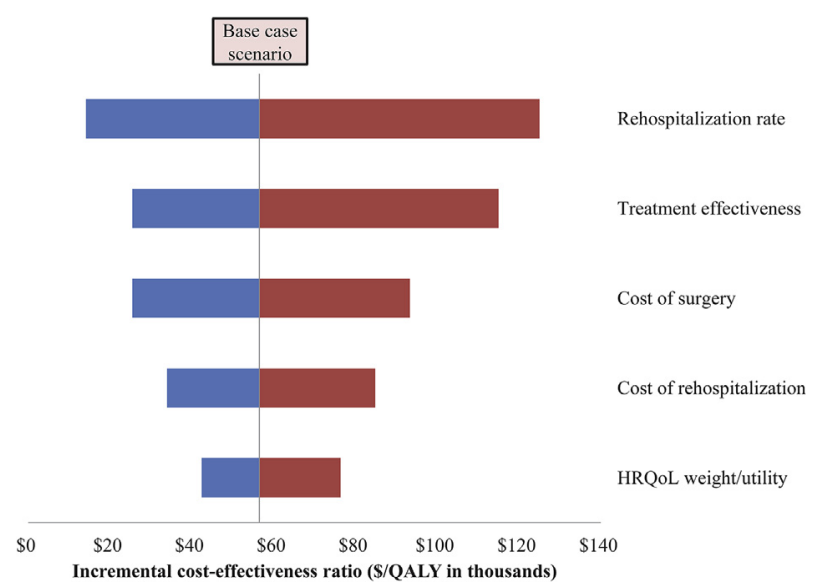

FIGURE 5. One-way deterministic sensitivity analyses across several model inputs. The base case scenario represents the ICER point estimate when comparing 2 surgeries. In deterministic sensitivity analysis, a given input, eg, the HRQoL weight, is varied in the model to determine how upper and lower bound assumptions impact outcomes. For example, when comparing surgery $A$ versus $B$, assuming a greater HRQoL after A lowers the ICER, as incremental QALYs increase. HRQoL, Health-related quality-of-life; $Q A L Y$, quality-adjusted life year. 
difficult, however, as the methods and sources for costs differed across studies: for estimation of inpatient costs, charges were converted into costs ${ }^{13,15,17}$ and/or payment data from fee-for-service Medicare beneficiaries were used. $^{15,18}$

Studies on BTT-LVADs showed a wide variation in improvement of QALYs when medical management was the comparator, sometimes resulting in very different conclusions on cost-effectiveness. For example, one study showed that LVAD therapy was both costlier and less effective than medical management (ie, dominated). ${ }^{20}$ However, this particular study assumed that patients with LVADs would receive transplants much later than those on medication and that mortality rates became equal across treatment groups during the "bridged period," both assumptions that are unjustified. All other studies assumed similar transplant rates across treatment groups and lower mortality with BTT-LVAD. ${ }^{17,19,21-24}$ The study with low incremental effectiveness ( 0.55 QALY) ${ }^{21}$ used relatively short time to transplant estimates, ie, an average waiting time of 6 months. In this study, BTT-LVADs were found to become much more cost-effective when assuming a longer time to transplant (18 months): the ICER decreased from $£ 258,922$ to $£ 133,860 / \mathrm{QALY}$. Time to transplant in other analyses was assumed to be much longer though (median time $\sim 45$ months), potentially explaining the apparently larger gain of $\sim 2.4$ QALYs and lower ICERs around $£ 55 \mathrm{~K} / \mathrm{QALY}{ }^{23,24}$

The variation in CEA findings for BTT-LVAD when medical management was the reference might be further explained by the lack of randomized trial data in the BTT realm. Therefore, survival rates during the "bridged" period had to be based on retrospective cohort series ${ }^{19,20,22}$ or on separate analyses of treatment arms in organ transplant and ventricular assist device registries, impeding appropriate confounder adjustment. ${ }^{17,21,23,24}$

For DT-LVAD, trial data were used to model survival, ${ }^{13,14}$ although CEAs comparing continuous-flow DT-LVAD with medical management were based on an indirect comparison from RCTs on pulsatile LVAD versus medical management and continuous-flow versus pulsatile LVAD. ${ }^{15,16}$ Other CEAs used data from ventricular assist device registries for the latter comparison. ${ }^{17,18}$

The question arises whether the findings from CEAs of LVAD versus medical management are in agreement with clinical practice guidelines endorsing the use of both DT- and BTT-LVADs in end-stage HF (class IIa recommendation) ${ }^{54-57}$ CEAs in recent years show ICERs that can be considered borderline acceptable, especially at a generally higher societal willingness-to-pay in the context of end-of-life care. ${ }^{58,59}$ Because it is difficult to use economic arguments for contesting the current practice of LVAD, a procedure that has been shown to save lives and improve QoL, it may become more relevant to evaluate the use of different next-generation LVADs, such as HeartWare (HeartWare International Inc, Framingham, Mass) and HeartMate 3 (Abbott Laboratories, Abbott Park, Ill), within CEA. ${ }^{25}$ Recently 2 RCTs were published comparing these newer centrifugal-flow devices with the existing axial-flow LVADs, as DT ${ }^{60}$ and DT/BTT. ${ }^{61}$ Both trials showed that centrifugal-flow LVADs have similar survival and are associated with lower device failure rates, although in transplant-ineligible patients they may result in greater stroke rates. ${ }^{60}$

Beginning with the seminal Randomized Evaluation of Mechanical Assistance for the Treatment of Congestive Heart Failure (REMATCH) trial, ${ }^{62}$ LVADs have served as one of the most highly studied modern cardiac surgical devices, transforming the contemporary management of end-stage HF. LVADs represent an effective yet costly therapy, with significant variability in cost-effectiveness outcomes across studies. Device experience has driven device innovation and improved patient selection which, in turn, has resulted in improved clinical outcomes and ICERs. Although CEA findings do not currently enter into formal consensus guideline recommendations in the United States, they are nevertheless critical for understanding the balance between the clinical need of advanced HF therapy with availability of resources ${ }^{59}$ and serving as benchmarks for next-generation devices.

\section{DISCUSSION}

The importance of integrating CEA into decision-making in cardiac surgery continues to grow with the greater emphasis on value-based care and the development of novel devices and procedures. ${ }^{63-68}$ With constrained resources, payers will increasingly take into account value (ie, cost, per unit outcome) in making coverage and reimbursement decisions regarding new surgical interventions. ${ }^{11,12}$ Moreover, with the movement toward population health management-where health care systems are responsible for the long-term health outcomes and costs of the populations they serve-economic analyses have become increasingly relevant for clinical decision making.

At the same time, analyzing the cost-effectiveness of cardiac surgery poses some methodologic challenges. Often, cardiac surgery interventions have high upfront costs and risks that may be off-set by long-term gains in survival, QoL, and reductions in morbidity and health care resource use. As such, the selection of a study's time horizon can substantially impact the results. ${ }^{51,52,69}$

Another challenge is related to the innovative nature of cardiac surgery, which may include the development or incremental modification of devices or ongoing changes in surgical technique, patient selection, and perioperative management of patients. ${ }^{70}$ As such, CEAs need to address the "moving target phenomenon," either by incorporating potential changes into sensitivity analyses or by planned 
reassessments. For example, the improvements of axial and continuous-flow LVADs over pulsatile LVADs have necessitated updated CEAs, with substantial improvements in its ICER relative to medical management. ${ }^{59}$ Now that DT and BTT-LVADs have been widely supported by clinical guideline societies and with the approval of centrifugalflow device technology, comparative CEA of currently available devices becomes more relevant.

The usefulness of CEA depends heavily on the quality of the underlying data and assumptions for synthesis and extrapolation of the evidence selected. Care delivered and the patients who participate in research studies may not be representative for the usual practice, limiting generalizability of findings. In the absence of robust long-term follow-up data on both clinical and economic outcomes and good cost estimation methodology, CEAs on the same topic may vary, even when the perspective and setting is similar, as shown for the CEAs concerning LVADs. Criteria for a useful CEA are summarized in Table E5.

Fortunately, the ability to generate data to conduct CEAs is improving. One important development has been the investment made by hospitals and large health systems in electronic health records and cost data, which are increasingly accessible through data warehouses. ${ }^{71}$ Moreover, economic data are increasingly recognized by research funding agencies as an important component of research (trials and other prospective studies) to evaluate new interventions. ${ }^{26}$ Linkages between registries, such as the Society of Thoracic Surgeons (STS) National Database, ${ }^{72}$ and national databases, such as the Medicare database, represent opportunities to track longer term outcomes and health resource use. In addition to its other databases, STS has established the STS/American College of Cardiology Transcatheter Valve Therapy Registry to track 30-day and 1-year outcomes for institutions conducting transcatheter aortic and mitral-valve repair or replacement operations. ${ }^{68,73}$ Estimation of costs could, however, be improved by drawing on more detailed and accurate internal cost-measuring systems adopted by many US hospitals instead of relying on indirect estimation using charges. ${ }^{74}$

Traditionally, most CEAs have been designed to give answers for the "average" patient or patient population as a whole, receiving "average" care. However, when treatment effects are heterogeneous, approaching decision problems from such a "one-size fits all" perspective will lead to suboptimal outcomes in patient subgroups. Yet, in an era of increasing individualization of care, there is a greater demand for CEAs that also provide results applicable to the individual patient. For example, when older age and greater comorbidity are associated with greater immediate surgical risks and costs, less-invasive treatments may become more attractive, especially when the downstream benefits with surgery are foreseen to get minimized by the patient's limited life expectancy. Because CEAs aim to integrate all potential harms and benefits within the analysis, individualized CEAs are uniquely positioned to improve patient selection and guide personalized medical decision-making, further optimizing value of care. ${ }^{75}$

Understanding the methods underlying CEA is critical in this environment of constrained resources and ongoing policy changes that affect financial incentives in order to ensure clinical participation in further shaping the health care system. ${ }^{76}$

\section{Conflict of Interest Statement}

Authors have nothing to disclose with regard to commercial support.

\section{References}

1. Mozaffarian D, Benjamin EJ, Go AS, Arnett DK, Blaha MJ, Cushman M, et al. Heart disease and stroke statistics-2016 update: a report from the American Heart Association. Circulation. 2016;133:e38-360.

2. Nkomo VT, Gardin JM, Skelton TN, Gottdiener JS, Scott CG, EnriquezSarano M. Burden of valvular heart diseases: a population-based study Lancet. 2006;368:1005-11.

3. Ad N, Suri RM, Gammie JS, Sheng S, O'Brien SM, Henry L. Surgical ablation of atrial fibrillation trends and outcomes in North America. J Thorac Cardiovasc Surg. 2012;144:1051-60.

4. Anderson JL, Heidenreich PA, Barnett PG, Creager MA, Fonarow GC, Gibbons RJ, et al. ACC/AHA statement on cost/value methodology in clinical practice guidelines and performance measures: a report of the American College of Cardiology/American Heart Association Task Force on Performance Measures and Task Force on Practice Guidelines. J Am Coll Cardiol. 2014;63: 2304-22.

5. Koeckert MS, Ursomanno PA, Williams MR, Querijero M, Zias EA, Loulmet DF, et al. Reengineering valve patients' postdischarge management for adapting to bundled payment models. J Thorac Cardiovasc Surg. 2017;154:190-8.

6. Matchar DB, Mark DB. Strategies for incorporating resource allocation and economic considerations: American College of Chest Physicians EvidenceBased Clinical Practice Guidelines (8th Edition). Chest. 2008;133:132s-40s.

7. Neumann PJ, Sanders GD. Cost-effectiveness analysis 2.0. N Engl J Med. 2017; 376:203-5.

8. Sanders GD, Neumann PJ, Basu A, Brock DW, Feeny D, Krahn M, et al. Recommendations for conduct, methodological practices, and reporting of cost-effectiveness analyses: second panel on cost-effectiveness in health and medicine. JAMA. 2016;316:1093-103.

9. Institute for Clinical and Economic Review. Available at: https://icer-review. org/methodology/icers-methods/icer-value-assessment-framework/. Accessed September 5, 2017.

10. Centers for Disease Control and Prevention. Available at: https://www.cdc.gov/ vaccines/acip/committee/guidance/economic-studies.html. Accessed September 5, 2017.

11. Parikh RB, Milstein A, Jain SH. Getting real about health care costs — a broader approach to cost stewardship in medical education. N Engl J Med. 2017;376: 913-5.

12. Cooke M. Cost consciousness in patient care-what is medical education's responsibility? N Engl J Med. 2010;362:1253-5.

13. Samson D. Special report: cost-effectiveness of left-ventricular assist devices as destination therapy for end-stage heart failure. Technol Eval Cent Asses. Program Exec Summ. 2004;19:1.

14. Clegg AJ, Scott DA, Loveman E, Colquitt J, Royle P, Bryant J. Clinical and cost-effectiveness of left ventricular assist devices as destination therapy for people with end-stage heart failure: a systematic review and economic evaluation. Int J Technol Assess Health Care. 2007;23:261-8. 
15. Rogers JG, Bostic RR, Tong KB, Adamson R, Russo M, Slaughter MS. Cost-effectiveness analysis of continuous-flow left ventricular assist devices as destination therapy. Circ Heart Fail. 2012;5:10-6.

16. Neyt M, Van den Bruel A, Smit Y, De Jonge N, Erasmus M, Van Dijk D, et al. Cost-effectiveness of continuous-flow left ventricular assist devices. Int $J$ Technol Assess Health Care. 2013;29:254-60.

17. Long EF, Swain GW, Mangi AA. Comparative survival and cost-effectiveness of advanced therapies for end-stage heart failure. Circ Heart Fail. 2014;7:470-8.

18. Baras Shreibati J, Goldhaber-Fiebert JD, Banerjee D, Owens DK, Hlatky MA. Cost-effectiveness of left ventricular assist devices in ambulatory patients with advanced heart failure. JACC Heart Fail. 2016;5:110-9.

19. Clegg AJ, Scott DA, Loveman E, Colquitt JL, Royle P, Bryant J. Clinical and cost-effectiveness of left ventricular assist devices as a bridge to heart transplantation for people with end-stage heart failure: a systematic review and economic evaluation. Eur Heart J. 2006;27:2929-38.

20. Sharples LD, Dyer M, Cafferty F, Demiris N, Freeman C, Banner NR, et al. Cost-effectiveness of ventricular assist device use in the United Kingdom: results from the evaluation of ventricular assist device programme in the UK (EVAD-UK). J Heart Lung Transplant. 2006;25:1336-43.

21. Moreno SG, Novielli N, Cooper NJ. Cost-effectiveness of the implantable HeartMate II left ventricular assist device for patients awaiting heart transplantation. J Heart Lung Transplant. 2012;31:450-8.

22. Alba AC, Alba LF, Delgado DH, Rao V, Ross HJ, Goeree R. Cost-effectiveness of ventricular assist device therapy as a bridge to transplantation compared with nonbridged cardiac recipients. Circulation. 2013;127:2424-35.

23. Sutcliffe P, Connock M, Pulikottil-Jacob R, Kandala NB, Suri G, Gurung T, et al. Clinical effectiveness and cost-effectiveness of second- and thirdgeneration left ventricular assist devices as either bridge to transplant or alternative to transplant for adults eligible for heart transplantation: systematic review and cost-effectiveness model. Health Technol Assess. 2013;17:1-499. $\mathrm{v}$-vi.

24. Clarke A, Pulikottil-Jacob R, Connock M, Suri G, Kandala NB, Maheswaran H, et al. Cost-effectiveness of left ventricular assist devices (LVADS) for patients with advanced heart failure: analysis of the British NHS bridge to transplant (BTT) program. Int J Cardiol. 2014;171:338-45.

25. Pulikottil-Jacob R, Suri G, Connock M, Kandala NB, Sutcliffe P, Maheswaran H, et al. Comparative cost-effectiveness of the HeartWare versus HeartMate II left ventricular assist devices used in the United Kingdom National Health Service Bridge-to-Transplant Program for patients with heart failure. J Heart Lung Transplant. 2014:33:350-8

26. Ramsey S, Willke R, Briggs A, Brown R, Buxton M, Chawla A, et al. Good research practices for cost-effectiveness analysis alongside clinical trials: the ISPOR RCT-CEA Task Force report. Value Health. 2005;8:521-33.

27. Tumeh JW, Moore SG, Shapiro R, Flowers CR. Practical approach for using Medicare data to estimate costs for cost-effectiveness analysis. Expert Rev Pharmacoecon Outcomes Res. 2005;5:153-62.

28. Hunink MGM, Weinstein MC, Wittenberg E, Drummond MF, Pliskin JS, Wong JB, et al. Decision Making in Health and Medicine: Integrating Evidence and Values. 2nd ed. Cambridge, UK: Cambridge University Press; 2014.

29. Glick HA, Doshi JA, Sonnad SS, Polsky D. Economic Evaluation in Clinical Trials. New York: Oxford University Press; 2007.

30. Dalton K. A Study of Charge Compression in Calculating DRG Relative Weights. Research Triangle Park, NC: RTI International; 2007.

31. Dalton K, Freeman S, Bragg A. Refining Cost to Charge Ratios for Calculating $A P C$ and MS-DRG Relative Payment Weights. Research Triangle Park, NC: RTI International; 2008.

32. McCarthy FH, Savino DC, Brown CR, Bavaria JE, Kini V, Spragan DD, et al. Cost and contribution margin of transcatheter versus surgical aortic valve replacement. J Thorac Cardiovasc Surg. 2017;154:1872-80.e1.

33. McCarthy FH, Spragan DD, Savino D, Dibble T, Hoedt AC, McDermott KM, et al. Outcomes, readmissions, and costs in transfemoral and alterative access transcatheter aortic valve replacement in the US Medicare population. J Thorac Cardiovasc Surg. 2017;154:1224-32.e1.

34. Riley GF. Administrative and claims records as sources of health care cost data. Med Care. 2009;47:S51-5.

35. Afana M, Brinjikji W, Cloft H, Salka S. Hospitalization costs for acute myocardial infarction patients treated with percutaneous coronary intervention in the United States are substantially higher than Medicare payments. Clin Cardiol. 2015;38:13-9.

36. Research Data Assistance Center. Available at: https://www.resdac.org/training/ workshops/intro-economic-research/media/10. Accessed September 5, 2017.
37. Taira DA, Seto TB, Siegrist R, Cosgrove R, Berezin R, Cohen DJ. Comparison of analytic approaches for the economic evaluation of new technologies alongside multicenter clinical trials. Am Heart J. 2003;145:452-8.

38. Maeda JL, Raetzman SO, Friedman BS. What hospital inpatient services contributed the most to the 2001-2006 growth in the cost per case? Health Serv Res. 2012;47:1814-35.

39. Sun Y, Friedman B. Tools for More Accurate Inpatient Cost Estimates With HCUP Databases, 2009. Errata added October 25, 2012. HCUP Methods Series. Rockville, MD: U.S. Agency for Healthcare Research and Quality; 2012.

40. Cameron HL, Bernard LM, Garmo VS, Hernandez JB, Asgar AW. A Canadian cost-effectiveness analysis of transcatheter mitral valve repair with the MitraClip system in high surgical risk patients with significant mitral regurgitation. J Med Econ. 2014;17:599-615.

41. Guerin P, Bourguignon S, Jamet N, Marque S. MitraClip therapy in mitral regurgitation: a Markov model for the cost-effectiveness of a new therapeutic option. J Med Econ. 2016;19:696-701.

42. Hlatky MA, Boothroyd DB, Melsop KA, Brooks MM, Mark DB, Pitt B, et al. Medical costs and quality of life 10 to 12 years after randomization to angioplasty or bypass surgery for multivessel coronary artery disease. Circulation. 2004;110: 1960-6.

43. Magnuson EA, Farkouh ME, Fuster V, Wang K, Vilain K, Li H, et al. Cost-effectiveness of percutaneous coronary intervention with drug eluting stents versus bypass surgery for patients with diabetes mellitus and multivessel coronary artery disease: results from the FREEDOM trial. Circulation. 2013; 127:820-31.

44. Reynolds MR, Lei Y, Wang K, Chinnakondepalli K, Vilain KA, Magnuson EA, et al. Cost-effectiveness of transcatheter aortic valve replacement with a self-expanding prosthesis versus surgical aortic valve replacement. J Am Coll Cardiol. 2016;67:29-38.

45. Fryback DG, Palta M, Cherepanov D, Bolt D, Kim JS. Comparison of 5 health-related quality-of-life indexes using item response theory analysis. Med Decis Making. 2010;30:5-15.

46. Garster NC, Palta M, Sweitzer NK, Kaplan RM, Fryback DG. Measuring health-related quality of life in population-based studies of coronary heart disease: comparing six generic indexes and a disease-specific proxy score. Qual Life Res. 2009;18:1239-47.

47. Sullivan PW, Ghushchyan V. Preference-based EQ-5D index scores for chronic conditions in the United States. Med Decis Making. 2006;26:410-20.

48. Hogendoorn W, Moll FL, Sumpio BE, Hunink MG. Clinical decision analysis and Markov modeling for surgeons: an introductory overview. Ann Surg. 2016; 264:268-74.

49. Sonnenberg FA, Beck JR. Markov models in medical decision making: a practical guide. Med Decis Making. 1993;13:322-38.

50. Rao C, Aziz O, Panesar SS, Jones C, Morris S, Darzi A, et al. Cost effectiveness analysis of minimally invasive internal thoracic artery bypass versus percutaneous revascularisation for isolated lesions of the left anterior descending artery. BMJ. 2007:334:621.

51. van Breugel NH, Bidar E, Essers BA, Nieman FH, Accord RE, Severens JL, et al. Cost-effectiveness of ablation surgery in patients with atrial fibrillation undergoing cardiac surgery. Interact Cardiovasc Thorac Surg. 2011;12:394-8.

52. Quenneville SP, Xie X, Brophy JM. The cost-effectiveness of maze procedures using ablation techniques at the time of mitral valve surgery. Int J Technol Assess Health Care. 2009;25:485-96.

53. Briggs AH, Weinstein MC, Fenwick EA, Karnon J, Sculpher MJ, Paltiel AD Model parameter estimation and uncertainty analysis: a report of the ISPOR-SMDM Modeling Good Research Practices Task Force Working Group-6. Med Decis Making. 2012;32:722-32.

54. Yancy CW, Jessup M, Bozkurt B, Butler J, Casey DE Jr, Drazner MH, et al. 2013 ACCF/AHA guideline for the management of heart failure: executive summary: a report of the American College of Cardiology Foundation/American Heart Association Task Force on Practice Guidelines. Circulation. 2013;128:1810-52.

55. Yancy CW, Jessup M, Bozkurt B, Butler J, Casey DE Jr, Colvin MM, et al. 2017 ACC/AHA/HFSA Focused Update of the 2013 ACCF/AHA Guideline for the Management of Heart Failure: A Report of the American College of Cardiology/American Heart Association Task Force on Clinical Practice Guidelines and the Heart Failure Society of America. J Am Coll Cardiol. 2017;70: 776-803.

56. Ponikowski P, Voors AA, Anker SD, Bueno H, Cleland JG, Coats AJ, et al. 2016 ESC Guidelines for the diagnosis and treatment of acute and chronic heart failure: The Task Force for the diagnosis and treatment of acute and chronic heart failure of the European Society of Cardiology (ESC). Developed with the special 
contribution of the Heart Failure Association (HFA) of the ESC. Eur J Heart Fail. 2016;18:891-975.

57. Feldman D, Pamboukian SV, Teuteberg JJ, Birks E, Lietz K, Moore SA, et al. The 2013 International Society for Heart and Lung Transplantation guidelines for mechanical circulatory support: executive summary. J Heart Lung Transplant. 2013;32:157-87.

58. Collins M, Latimer N. Nice's end of life decision making scheme: impact on population health. BMJ. 2013;346:f1363.

59. Entwistle JWC III. The American Association for Thoracic Surgery 2016 Ethics Forum: "Cost-effectiveness and the ethics of left ventricular assist device therapy." J Thorac Cardiovasc Surg. 2017;154:1315-8.

60. Rogers JG, Pagani FD, Tatooles AJ, Bhat G, Slaughter MS, Birks EJ, et al. Intrapericardial left ventricular assist device for advanced heart failure. $N$ Engl J Med. 2017;376:451-60.

61. Mehra MR, Naka Y, Uriel N, Goldstein DJ, Cleveland JC Jr, Colombo PC, et al. A fully magnetically levitated circulatory pump for advanced heart failure. N Engl J Med. 2017;376:440-50.

62. Rose EA, Gelijns AC, Moskowitz AJ, Heitjan DF, Stevenson LW, Dembitsky W, et al. Long-term use of a left ventricular assist device for end-stage heart failure. N Engl J Med. 2001;345:1435-43.

63. Beck DL. Destination Therapy: Given costs and complications, do we really want to go there? American College of Cardiology Web site. Available at: http://www. acc.org/latest-in-cardiology/articles/2015/07/22/14/55/cover-story-destinationtherapy. Accessed September 5, 2017.

64. Dhruva SS, Krumholz HM. The core value of cost-effectiveness analyses. J Am Coll Cardiol. 2016;67:39-41.

65. Fanari Z, Weintraub WS. Cost-effectiveness of transcatheter versus surgical management of structural heart disease. Cardiovasc Revasc Med. 2016;17:44-7.
66. Hlatky MA. Considering cost-effectiveness in cardiology clinical guidelines: progress and prospects. Value Health. 2016;19:516-9.

67. Mark DB, Hlatky MA. Medical economics and the assessment of value in cardiovascular medicine: part II. Circulation. 2002;106:626-30.

68. Pollak PM, Mack MJ, Holmes DR Jr. Quality, economics, and national guidelines for transcatheter aortic valve replacement. Prog Cardiovasc Dis. 2014;56:610-8.

69. Lamotte M, Annemans L, Bridgewater B, Kendall S, Siebert M. A health economic evaluation of concomitant surgical ablation for atrial fibrillation. Eur J Cardiothorac Surg. 2007:32:702-10.

70. Iribarne A, Russo MJ, Moskowitz AJ, Ascheim DD, Brown LD, Gelijns AC Assessing technological change in cardiothoracic surgery. Semin Thorac Cardiovasc Surg. 2009;21:28-34.

71. Atluri P, Stetson RL, Hung G, Gaffey AC, Szeto WY, Acker MA, et al. Minimally invasive mitral valve surgery is associated with equivalent cost and shorter hospital stay when compared with traditional sternotomy. J Thorac Cardiovasc Surg. 2016;151:385-8

72. The Society of Thoracic Surgeons. STS National Database. Available at: https:// www.sts.org/national-database. Accessed September 5, 2017.

73. American College of Cardiology Foundation. The STS/ACC TVT Registry. Available at: https://www.ncdr.com/webncdr/tvt/publicpage. Accessed September 5, 2017

74. Ederhof M, Ginsburg PB. Improving hospital incentives with better cost data. N Engl J Med. 2017;376:1010-1.

75. Ioannidis JP, Garber AM. Individualized cost-effectiveness analysis. PLoS Med 2011;8:e1001058.

76. Iribarne A, Easterwood R, Russo MJ, Wang YC. Integrating economic evaluation methods into clinical and translational science award consortium comparative effectiveness educational goals. Acad Med. 2011;86:701-5. 


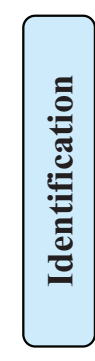

Records identified through database searching

$(\mathrm{n}=1020)$

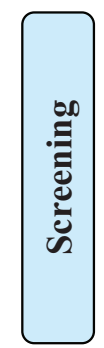

Records after duplicates removed

$(\mathrm{n}=1020)$

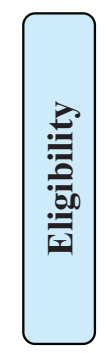

Full-text articles excluded $(\mathrm{n}=62)$

Not primary CEA $(\mathrm{n}=52)$

Results duplicated $(\mathrm{n}=3)$

No surgical intervention

$(\mathrm{n}=7)$

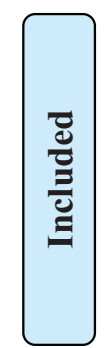

Additional records identified through other sources $(\mathrm{n}=2)$

FIGURE E1. Preferred Reporting Items for Systematic Reviews and Meta-Analyses (PRISMA) flow diagram of study inclusion. CEA, Cost-effectiveness analysis. 
TABLE E1. Summary of cost-effectiveness analysis findings for aortic stenosis

\begin{tabular}{|c|c|c|c|c|c|c|c|c|}
\hline Author & Year & Comparison & Country & Horizon & Cost year & $\Delta$ Costs & $\Delta$ Effectiveness $*$ & ICER* \\
\hline \multicolumn{9}{|l|}{ Inoperable } \\
\hline $\begin{array}{l}\text { Gada and } \\
\text { colleagues }^{\mathrm{E} 1}\end{array}$ & 2012 & TA TAVR vs MM & USA & Lifetime & 2012 & NR & NR & $\$ 44,384$ \\
\hline $\begin{array}{l}\text { Gada and } \\
\text { colleagues }^{\mathrm{E} 2}\end{array}$ & 2012 & TF TAVR vs MM & USA & Lifetime & 2011 & NR & NR & $\$ 39,964$ \\
\hline $\begin{array}{l}\text { Neyt and } \\
\text { colleagues }^{\mathrm{E} 3}\end{array}$ & 2012 & TF TAVR vs MM & Belgium & Lifetime & NR & $€ 33,200$ & 0.74 & $€ 44,900$ \\
\hline $\begin{array}{l}\text { Reynolds and } \\
\text { colleagues }^{\mathrm{E} 4}\end{array}$ & 2012 & TF TAVR vs MM & USA & Lifetime & 2010 & $\$ 79,837$ & 1.29 & $\$ 61,889$ \\
\hline $\begin{array}{l}\text { Watt and } \\
\text { colleagues }^{\mathrm{E} 5}\end{array}$ & 2012 & TF TAVR vs MM & $\begin{array}{l}\text { United } \\
\text { Kingdom }\end{array}$ & $10 \mathrm{y}$ & 2010 & $£ 25,200$ & 1.56 & $£ 16,200$ \\
\hline $\begin{array}{l}\text { Doble and } \\
\text { colleagues }^{\mathrm{E} 6}\end{array}$ & 2013 & TF TAVR vs MM & Canada & $20 \mathrm{y}$ & 2010 & $\$ 31,028(\mathrm{CAD})$ & 0.60 & $\$ 51,324(\mathrm{CAD})$ \\
\hline $\begin{array}{l}\text { Hancock- } \\
\text { Howard and } \\
\text { colleagues }^{\mathrm{E} 7}\end{array}$ & 2013 & TF TAVR vs MM & Canada & $3 y$ & 2009 & $\$ 15,687$ (CAD) & 0.49 & $\$ 32,170(\mathrm{CAD})$ \\
\hline $\begin{array}{l}\text { Murphy and } \\
\text { colleagues }^{\mathrm{E} 8}\end{array}$ & 2013 & TF TAVR vs MM & $\begin{array}{l}\text { United } \\
\text { Kingdom }\end{array}$ & Lifetime & NR & $£ 15,885$ & 0.44 & $£ 35,956$ \\
\hline $\begin{array}{c}\text { Sehatzadeh and } \\
\text { colleagues }^{\mathrm{E} 9}\end{array}$ & 2013 & TAVR vs MM & Canada & Lifetime & NR & $\$ 15,233(\mathrm{CAD})$ & 0.628 & $\$ 24,257$ (CAD) \\
\hline $\begin{array}{l}\text { Simons and } \\
\text { colleagues }^{\mathrm{E} 10}\end{array}$ & 2013 & TF TAVR vs MM & USA & Lifetime & 2010 & $\$ 85,600$ & 0.73 & $\$ 116,500$ \\
\hline \multirow[t]{2}{*}{$\begin{array}{l}\text { Brecker and } \\
\text { colleagues }^{\mathrm{E} 11}\end{array}$} & 2014 & $\begin{array}{l}\text { TAVR vs MM } \\
\quad \text { (EuroSCORE } \\
\geq 20 \% \text { ) }\end{array}$ & $\begin{array}{l}\text { United } \\
\quad \text { Kingdom }\end{array}$ & $5 \mathrm{y}$ & NR & $£ 22,009$ & 1.24 & $£ 17,718$ \\
\hline & & $\begin{array}{l}\text { TAVR vs MM } \\
\text { (EuroSCORE } \\
\quad<20 \% \text { ) }\end{array}$ & $\begin{array}{l}\text { United } \\
\text { Kingdom }\end{array}$ & $5 \mathrm{y}$ & NR & $£ 21,038$ & 1.51 & $£ 13,943$ \\
\hline $\begin{array}{l}\text { Freeman and } \\
\text { colleagues }^{\mathrm{E} 12}\end{array}$ & 2016 & TAVR vs MM & $\begin{array}{l}\text { United } \\
\text { Kingdom }\end{array}$ & $5 y$ & 2012 & $£ 13,655$ & 1.29 & $£ 10,533$ \\
\hline \multicolumn{9}{|l|}{ High risk } \\
\hline $\begin{array}{l}\text { Gada and } \\
\text { colleagues }^{\mathrm{E} 1}\end{array}$ & 2012 & $\begin{array}{l}\text { TA TAVR vs } \\
\text { SAVR }\end{array}$ & USA & Lifetime & 2012 & $\$ 100$ & -0.04 & $\begin{array}{c}\text { TAVR dominated } \\
\text { by SAVR }\end{array}$ \\
\hline $\begin{array}{l}\text { Gada and } \\
\text { colleagues }^{\mathrm{E} 2}\end{array}$ & 2012 & $\begin{array}{l}\text { TF TAVR vs } \\
\text { SAVR }\end{array}$ & USA & Lifetime & 2011 & $\$ 3164$ & 0.06 & $\$ 52,733$ \\
\hline $\begin{array}{l}\text { Neyt and } \\
\text { colleagues }^{\mathrm{E} 3}\end{array}$ & 2012 & $\begin{array}{l}\text { TF or TA TAVR vs } \\
\text { SAVR }\end{array}$ & Belgium & $1 \mathrm{y}$ & NR & $€ 20,397$ & 0.03 & $€ 750,000$ \\
\hline \multirow[t]{2}{*}{$\begin{array}{l}\text { Reynolds and } \\
\text { colleagues }^{\mathrm{E} 13}\end{array}$} & 2012 & $\begin{array}{l}\text { TF TAVR vs } \\
\text { SAVR }\end{array}$ & USA & $12 \mathrm{mo}$ & 2010 & $-\$ 1250$ & 0.068 & TAVR dominant \\
\hline & & $\begin{array}{l}\text { TA TAVR vs } \\
\text { SAVR }\end{array}$ & USA & $12 \mathrm{mo}$ & 2010 & $\$ 9906$ & -0.07 & TAVR dominated \\
\hline $\begin{array}{l}\text { Doble and } \\
\text { colleagues }^{\mathrm{E} 6}\end{array}$ & 2013 & $\begin{array}{l}\text { TF or TA TAVR vs } \\
\text { SAVR }\end{array}$ & Canada & $20 \mathrm{y}$ & 2010 & $\$ 11,153(\mathrm{CAD})$ & -0.102 & $\begin{array}{c}\text { TAVR dominated } \\
\text { by SAVR }\end{array}$ \\
\hline $\begin{array}{l}\text { Fairbairn and } \\
\text { colleagues }^{\mathrm{E} 14}\end{array}$ & 2013 & TAVR vs SAVR & $\begin{array}{l}\text { United } \\
\text { Kingdom }\end{array}$ & $10 \mathrm{y}$ & NR & $-£ 1350$ & 0.063 & $\begin{array}{c}\text { TAVR dominates } \\
\text { SAVR }\end{array}$ \\
\hline $\begin{array}{c}\text { Sehatzadeh and } \\
\text { colleagues }^{\mathrm{E} 9}\end{array}$ & 2013 & TAVR vs SAVR & Canada & Lifetime & NR & $-\$ 4642(\mathrm{CAD})$ & -0.069 & $\$ 66,985$ (CAD) \\
\hline $\begin{array}{l}\text { Reynolds and } \\
\text { colleagues }^{\mathrm{E} 15}\end{array}$ & 2016 & TAVR vs SAVR & USA & Lifetime & 2013 & $\$ 17,849$ & 0.32 & $\$ 55,090$ \\
\hline \multicolumn{9}{|l|}{ Intermediate risk } \\
\hline $\begin{array}{l}\text { Ribera and } \\
\text { colleagues }\end{array}$ & 2015 & $\begin{array}{l}\text { Edwards SAPIEN } \\
\text { TF TAVR vs } \\
\text { SAVR }\end{array}$ & Spain & $1 \mathrm{y}$ & 2012 & $€ 8800$ & 0.036 & $€ 148,525$ \\
\hline
\end{tabular}


TABLE E1. Continued

\begin{tabular}{|c|c|c|c|c|c|c|c|c|}
\hline Author & Year & Comparison & Country & Horizon & Cost year & $\Delta$ Costs & $\Delta$ Effectiveness $*$ & ICER* \\
\hline & & $\begin{array}{l}\text { Medtronic } \\
\text { CoreValve TF } \\
\text { TAVR vs SAVR }\end{array}$ & Spain & $1 \mathrm{y}$ & 2012 & $€ 9729$ & -0.011 & $\begin{array}{c}\text { TAVR dominated } \\
\text { by SAVR }\end{array}$ \\
\hline $\begin{array}{l}\text { Moore and } \\
\text { colleagues }^{\mathrm{E} 17}\end{array}$ & 2016 & $\begin{array}{l}\text { Edwards } \\
\text { INTUITY Elite } \\
\text { MIS-RDAVR vs } \\
\text { MISAVR vs } \\
\text { SAVR }\end{array}$ & USA & Lifetime & 2016 & $\begin{array}{c}\text { MIS-RDAVR vs } \\
\text { MISAVR: } \\
\$ 4560 ; \\
\text { MISAVR vs } \\
\text { SAVR: }-\$ 7181\end{array}$ & $\begin{array}{l}\text { MIS-RDAVR vs } \\
\text { MISAVR: } 0.2 ; \\
\text { MISAVR vs } \\
\text { SAVR: } 0.066\end{array}$ & $\begin{array}{l}\text { MISAVR } \\
\text { dominates } \\
\text { SAVR; MIS- } \\
\text { RDAVR vs } \\
\text { MISAVR: } \\
\$ 22,903\end{array}$ \\
\hline
\end{tabular}

$\overline{I C E R}$, Incremental cost-effectiveness ratio; $T A$, transapical; $T A V R$, transcatheter aortic valve replacement; $M M$, medical management; $N R$, not reported; $T F$, transfemoral; $C A D$, Canadian dollars; SAVR, surgical aortic valve replacement; MIS-RDAVR, minimally invasive surgical rapid-deployment aortic valve replacement; MISAVR, minimally invasive surgical aortic valve replacement. * $\triangle$ Effectiveness and ICERs were calculated using QALYs unless specified to be life-years.

TABLE E2. Summary of cost-effectiveness analysis findings for MR

\begin{tabular}{|c|c|c|c|c|c|c|c|c|c|}
\hline Author & Year & Population & Comparison & Country & Horizon & $\begin{array}{l}\text { Cost } \\
\text { year }\end{array}$ & $\Delta$ Costs & $\Delta$ Effectiveness $*$ & ICER* \\
\hline $\begin{array}{l}\text { Mealing and } \\
\text { colleagues }^{\mathrm{E} 18}\end{array}$ & 2013 & $\begin{array}{l}\text { Functional or } \\
\text { degenerative, } \\
\text { moderate/ } \\
\text { severe MR with } \\
\text { HF and high } \\
\text { surgical risk }\end{array}$ & $\begin{array}{r}\text { MitraClip } \\
\text { vs MM }\end{array}$ & $\begin{array}{l}\text { United } \\
\quad \text { Kingdom }\end{array}$ & Lifetime & 2011 & $£ 30,192$ & 2.04 & $£ 14,800$ \\
\hline $\begin{array}{l}\text { Cameron and } \\
\text { colleagues }^{\mathrm{E} 19}\end{array}$ & 2014 & $\begin{array}{l}\text { Functional or } \\
\text { degenerative, } \\
\text { moderate/ } \\
\text { severe MR with } \\
\text { HF and high } \\
\text { surgical risk }\end{array}$ & $\begin{array}{r}\text { MitraClip } \\
\text { vs MM }\end{array}$ & Canada & Lifetime & 2013 & $\$ 40,617$ (CAD) & 1.73 & $\$ 23,433$ (CAD) \\
\hline $\begin{array}{l}\text { Armeni and } \\
\text { colleagues }^{\text {E20 }}\end{array}$ & 2016 & $\begin{array}{l}\text { Functional, } \\
\text { moderate/ } \\
\text { severe MR with } \\
\text { HF }\end{array}$ & $\begin{array}{r}\text { MitraClip } \\
\text { vs MM }\end{array}$ & Italy & Lifetime & NR & $€ 23,342$ & 3.01 & $€ 7908$ \\
\hline $\begin{array}{l}\text { Asgar and } \\
\text { colleagues }^{\mathrm{E} 21}\end{array}$ & 2016 & $\begin{array}{l}\text { Functional, } \\
\text { moderate/ } \\
\text { severe MR with } \\
\text { HF and high } \\
\text { surgical risk }\end{array}$ & $\begin{array}{r}\text { MitraClip } \\
\text { vs MM }\end{array}$ & Canada & $10 \mathrm{y}$ & 2013 & $\$ 52,600(\mathrm{CAD})$ & 1.63 & $\$ 32,300(\mathrm{CAD})$ \\
\hline $\begin{array}{l}\text { Guerin and } \\
\text { colleagues }^{\text {E22 }}\end{array}$ & 2016 & $\begin{array}{l}\text { Functional or } \\
\text { degenerative, } \\
\text { moderate/ } \\
\text { severe MR with } \\
\text { HF and high } \\
\text { surgical risk }\end{array}$ & $\begin{array}{r}\text { MitraClip } \\
\text { vs MM }\end{array}$ & France & $5 \mathrm{y}$ & 2011 & $€ 26,974$ & 1.71 (LY) & $€ 15,741$ (/LY) \\
\hline
\end{tabular}

ICER, Incremental cost-effectiveness ratio; $M R$, mitral regurgitation; $H F$, heart failure; $M M$, medical management; $C A D$, Canadian dollars; $N R$, not reported; $L Y$, life-year. $* \triangle$ Effectiveness and ICERs were calculated using QALYs unless specified to be LYs. 
TABLE E3. Summary of cost-effectiveness analysis findings for AF

\begin{tabular}{|c|c|c|c|c|c|c|c|c|c|}
\hline Author & Year & Population & Comparison & Country & Horizon & $\begin{array}{l}\text { Cost } \\
\text { year }\end{array}$ & $\Delta$ Costs & $\Delta$ Effectiveness $*$ & ICER* \\
\hline \multirow[t]{3}{*}{$\begin{array}{l}\text { Lamotte and } \\
\text { colleagues }^{\mathrm{E} 23}\end{array}$} & 2007 & $\begin{array}{l}\text { Coronary or } \\
\text { valvular disease } \\
\text { undergoing } \\
\text { CABG or valve } \\
\text { replacement/ } \\
\text { repair with } \\
\text { permanent AF }\end{array}$ & $\begin{array}{l}\text { High-intensity } \\
\text { focused } \\
\text { ultrasound } \\
\text { surgical } \\
\text { ablation vs } \\
\text { maze vs } \\
\text { percutaneous } \\
\text { ablation vs MM }\end{array}$ & $\begin{array}{l}\text { United } \\
\text { Kingdom }\end{array}$ & $5 \mathrm{y}$ & & $\begin{array}{l}\text { Percutaneous } \\
\text { ablation vs } \\
\text { surgical } \\
\text { ablation: } £ 971 ; \\
\text { surgical } \\
\text { ablation vs } \\
\text { maze: } £ 1334 ; \\
\text { maze vs no } \\
\text { ablation: } £ 720\end{array}$ & $\begin{array}{l}\text { Percutaneous } \\
\text { ablation vs } \\
\text { surgical } \\
\text { ablation: } \\
-0.083 ; \\
\text { surgical } \\
\text { ablation vs } \\
\text { maze: }-0.0233 \text {; } \\
\text { maze vs no } \\
\text { ablation: } 0.536\end{array}$ & $\begin{array}{l}\text { Percutaneous } \\
\text { ablation } \\
\text { dominated by } \\
\text { surgical } \\
\text { ablation; } \\
\text { surgical } \\
\text { ablation } \\
\text { dominated by } \\
\text { maze; maze vs } \\
\text { no ablation: } \\
£ 1343\end{array}$ \\
\hline & & $\begin{array}{l}\text { Coronary or } \\
\text { valvular disease } \\
\text { undergoing } \\
\text { CABG or valve } \\
\text { replacement/ } \\
\text { repair with } \\
\text { persistent AF }\end{array}$ & $\begin{array}{l}\text { High-intensity } \\
\text { focused } \\
\text { ultrasound } \\
\text { surgical } \\
\text { ablation vs } \\
\text { maze vs } \\
\text { percutaneous } \\
\text { ablation vs MM }\end{array}$ & $\begin{array}{l}\text { United } \\
\text { Kingdom }\end{array}$ & $5 \mathrm{y}$ & 2005 & $\begin{array}{l}\text { Percutaneous } \\
\text { ablation vs } \\
\text { surgical } \\
\text { ablation: } £ 1010 \text {; } \\
\text { surgical } \\
\text { ablation vs } \\
\text { maze: } £ 1284 \text {; } \\
\text { maze vs no } \\
\text { ablation: } £ 885\end{array}$ & $\begin{array}{l}\text { Percutaneous } \\
\quad \text { ablation vs } \\
\text { surgical } \\
\text { ablation: } \\
-0.1082 ; \\
\text { surgical } \\
\text { ablation vs } \\
\text { maze: } 0.0362 ; \\
\text { maze vs no } \\
\text { ablation: } 0.255\end{array}$ & $\begin{array}{l}\text { Percutaneous } \\
\quad \text { ablation } \\
\text { dominated by } \\
\text { surgical } \\
\text { ablation; } \\
\text { surgical } \\
\text { ablation vs } \\
\text { maze: } £ 35,469 \text {; } \\
\text { maze vs no } \\
\text { ablation: } £ 3471\end{array}$ \\
\hline & & $\begin{array}{l}\text { Coronary or } \\
\text { valvular disease } \\
\text { undergoing } \\
\text { CABG or valve } \\
\text { replacement/ } \\
\text { repair with } \\
\text { paroxysmal AF }\end{array}$ & $\begin{array}{l}\text { High-intensity } \\
\text { focused } \\
\text { ultrasound } \\
\text { surgical } \\
\text { ablation vs } \\
\text { maze vs } \\
\text { percutaneous } \\
\text { ablation vs MM }\end{array}$ & $\begin{array}{l}\text { United } \\
\text { Kingdom }\end{array}$ & $5 \mathrm{y}$ & 2005 & $\begin{array}{l}\text { Percutaneous } \\
\text { ablation vs } \\
\text { surgical } \\
\text { ablation: } £ 981 \text {; } \\
\text { surgical } \\
\text { ablation vs } \\
\text { maze: } £ 1284 ; \\
\text { maze vs no } \\
\text { ablation: } £ 856\end{array}$ & $\begin{array}{l}\text { Percutaneous } \\
\text { ablation vs } \\
\text { surgical } \\
\text { ablation: } \\
-0.077 ; \\
\text { surgical } \\
\text { ablation vs } \\
\text { maze: } 0.0352 ; \\
\text { maze vs no } \\
\text { ablation: } 0.286\end{array}$ & $\begin{array}{l}\text { Percutaneous } \\
\quad \text { ablation } \\
\text { dominated by } \\
\text { surgical } \\
\text { ablation; } \\
\text { surgical } \\
\text { ablation vs } \\
\text { maze: } £ 36,477 \text {; } \\
\text { maze vs no } \\
\text { ablation: } £ 2991\end{array}$ \\
\hline $\begin{array}{c}\text { Quenneville and } \\
\text { colleagues }^{\mathrm{E} 24}\end{array}$ & 2009 & $\begin{array}{l}\text { Chronic AF } \\
\text { undergoing MV } \\
\text { surgery }\end{array}$ & $\begin{array}{l}\text { Concomitant } \\
\text { modified maze } \\
\text { vs MM }\end{array}$ & Canada & $15 \mathrm{y}$ & NR & $\$ 900(\mathrm{CAD})$ & 0.20 & $\$ 4446$ (CAD) \\
\hline $\begin{array}{c}\text { van Breugel and } \\
\text { colleagues }^{\mathrm{E} 25}\end{array}$ & 2011 & $\begin{array}{l}\text { Paroxysmal, } \\
\text { persistent, or } \\
\text { permanent } \mathrm{AF} \\
\text { undergoing } \\
\text { valvular and/or } \\
\text { coronary } \\
\text { surgery }\end{array}$ & $\begin{array}{l}\text { Concomitant } \\
\text { ablation surgery } \\
\text { vs MM }\end{array}$ & Netherlands & $1 \mathrm{y}$ & 2004 & $€ 4426$ & 0.06 & $€ 73,359$ \\
\hline $\begin{array}{l}\text { Anderson and } \\
\text { colleagues }^{\mathrm{E} 26}\end{array}$ & 2014 & $\begin{array}{l}\text { Symptomatic } \\
\text { nonparoxysmal } \\
\mathrm{AF}-\text { low event } \\
\text { rate risk cohort }\end{array}$ & $\begin{array}{l}\text { Convergent } \\
\text { procedure vs } \\
\text { catheter } \\
\text { ablation vs MM }\end{array}$ & USA & $5 \mathrm{y}$ & & $\begin{array}{l}\text { Convergent vs } \\
\text { catheter } \\
\text { ablation: } \\
\text {-\$357; } \\
\text { Catheter } \\
\text { ablation vs MM: } \\
\$ 15,809 ; \\
\text { Convergent vs } \\
\text { MM: } \$ 15,452\end{array}$ & $\begin{array}{l}\text { Convergent vs } \\
\text { catheter } \\
\text { ablation: } 0.23 \text {; } \\
\text { Catheter } \\
\text { ablation vs MM: } \\
0.52 ; \\
\text { Convergent vs } \\
\text { MM: } 0.75\end{array}$ & $\begin{array}{l}\text { Convergent } \\
\text { dominates } \\
\text { catheter } \\
\text { ablation; } \\
\text { convergent vs } \\
\text { MM: } \$ 20,640\end{array}$ \\
\hline
\end{tabular}

(Continued) 
TABLE E3. Continued

\begin{tabular}{|c|c|c|c|c|c|c|c|c|c|}
\hline Author & Year & Population & Comparison & Country & Horizon & $\begin{array}{l}\text { Cost } \\
\text { year }\end{array}$ & $\Delta$ Costs & $\Delta$ Effectiveness $*$ & ICER* \\
\hline & & $\begin{array}{l}\text { Symptomatic } \\
\text { nonparoxysmal } \\
\text { AF - medium } \\
\text { event rate risk } \\
\text { cohort. }\end{array}$ & $\begin{array}{l}\text { Convergent } \\
\text { procedure vs } \\
\text { catheter } \\
\text { ablation vs MM }\end{array}$ & USA & $5 y$ & & $\begin{array}{l}\text { Convergent vs } \\
\text { catheter } \\
\text { ablation: } \\
-\$ 4475 ; \\
\text { catheter } \\
\text { ablation vs MM: } \\
\text { \$6300; } \\
\text { convergent vs } \\
\text { MM: } \$ 1825\end{array}$ & $\begin{array}{l}\text { Convergent vs } \\
\text { catheter } \\
\text { ablation: } 0.26 \text {; } \\
\text { catheter } \\
\text { ablation vs MM } \\
0.56 ; \\
\text { convergent vs } \\
\text { MM: } 0.82\end{array}$ & $\begin{array}{l}\text { Convergent } \\
\text { dominates } \\
\text { catheter } \\
\text { ablation; } \\
\text { convergent vs } \\
\text { MM: \$2214 }\end{array}$ \\
\hline & & $\begin{array}{l}\text { Symptomatic } \\
\text { nonparoxysmal } \\
\mathrm{AF} \text { - high event } \\
\text { rate risk cohort. }\end{array}$ & $\begin{array}{l}\text { Convergent } \\
\text { procedure vs } \\
\text { catheter } \\
\text { ablation vs MM }\end{array}$ & USA & $5 \mathrm{y}$ & & $\begin{array}{l}\text { Convergent vs } \\
\text { catheter } \\
\text { ablation: } \\
-\$ 8337 ; \\
\text { catheter } \\
\text { ablation vs MM: } \\
-\$ 6336 ; \\
\text { convergent vs } \\
\text { MM: }-\$ 14,673\end{array}$ & $\begin{array}{l}\text { Convergent vs } \\
\text { catheter } \\
\text { ablation: } 0.28 \text {; } \\
\text { catheter } \\
\text { ablation vs MM: } \\
0.62 \text {; } \\
\text { convergent vs } \\
\text { MM: } 0.90\end{array}$ & $\begin{array}{l}\text { Convergent } \\
\text { dominates } \\
\text { catheter } \\
\text { ablation; } \\
\text { convergent } \\
\text { dominates MM }\end{array}$ \\
\hline
\end{tabular}

ICER, Incremental cost-effectiveness ratio; $C A B G$, coronary artery bypass graft; $A F$, atrial fibrillation; $M M$, medical management; $M V$, mitral valve; $N R$, not reported; $C A D$, Canadian dollars. * $\triangle$ Effectiveness and ICERs were calculated using QALYs unless specified to be life-years. 
TABLE E4. Summary of cost-effectiveness analysis findings for CAD

\begin{tabular}{|c|c|c|c|c|c|c|c|c|c|}
\hline Author & Year & Population & Comparison & Country & Horizon & Cost year & $\Delta$ Costs & $\Delta$ Effectiveness $*$ & ICER* \\
\hline $\begin{array}{l}\text { Eefting and } \\
\text { colleagues }^{\mathrm{E} 27}\end{array}$ & 2003 & Single- or multivessel & $\begin{array}{l}\text { Off-pump CABG vs } \\
\text { PCI stents }\end{array}$ & The Netherlands & $1 \mathrm{y}$ & 1999 & $\begin{array}{l}\text { 7332.5 Dutch } \\
\text { Florins }\end{array}$ & -0.03 & $\begin{array}{l}\text { Off-pump CABG } \\
\text { dominated by PCI }\end{array}$ \\
\hline $\begin{array}{l}\text { Hlatky and } \\
\text { colleagues } 28\end{array}$ & 2004 & Multivessel & $\begin{array}{l}\text { CABG vs PCI no } \\
\text { stents }\end{array}$ & USA & $12 \mathrm{y}$ & 2002 & $\$ 2250$ & $0.16(\mathrm{LY})$ & $\$ 14,300(/ \mathrm{LY})$ \\
\hline $\begin{array}{l}\text { Nathoe and } \\
\text { colleagues }^{\mathrm{E} 29}\end{array}$ & 2005 & Single- or multivessel & $\begin{array}{l}\text { Off-pump CABG vs } \\
\text { PCI stents }\end{array}$ & The Netherlands & $1 \mathrm{y}$ & 1999 & $€ 2813$ & -0.03 & $\begin{array}{l}\text { Off-pump CABG } \\
\text { dominated by PCI. }\end{array}$ \\
\hline $\begin{array}{l}\text { Stroupe and } \\
\text { colleagues }^{\mathrm{E} 30}\end{array}$ & 2006 & $\begin{array}{l}\text { Medically refractory } \\
\text { myocardial } \\
\text { ischemia, high-risk } \\
\text { adverse outcomes }\end{array}$ & $\begin{array}{l}\text { CABG vs PCI (some } \\
\text { stenting); urgent } \\
\text { revascularization }\end{array}$ & USA & $5 \mathrm{y}$ & 2004 & $\$ 18,732$ & -0.05 & $\begin{array}{l}\text { CABG dominated by } \\
\text { PCI }\end{array}$ \\
\hline $\begin{array}{l}\text { Kastanioti and } \\
\text { colleagues }^{\mathrm{E} 31}\end{array}$ & 2007 & Single- or multivessel & CABG vs PCI vs MM & Greece & $1 \mathrm{y}$ & NR & -3447 & 0.03 & NR \\
\hline $\begin{array}{l}\text { Magnuson and } \\
\text { colleagues }^{\mathrm{E} 32}\end{array}$ & 2013 & $\begin{array}{l}\text { Multivessel w/ } \\
\text { diabetes }\end{array}$ & CABG vs PCI DES & USA & Lifetime & 2010 & $\$ 5392$ & 0.663 & $\$ 8132$ \\
\hline $\begin{array}{l}\text { Cohen and } \\
\text { colleagues }^{\mathrm{E} 33}\end{array}$ & 2014 & $\begin{array}{l}\text { Multivessel or left } \\
\text { main }\end{array}$ & CABG vs PCI DES & USA & Lifetime & 2010 & $\$ 5081$ & 0.307 & $\$ 16,537$ \\
\hline $\begin{array}{l}\text { Javanbakht and } \\
\text { colleagues }^{\mathrm{E} 34}\end{array}$ & 2014 & Multivessel & CABG vs PCI stents & Iran & Lifetime & 2011 & $-\$ 4761$ & 0.41 & CABG dominated PCI \\
\hline $\begin{array}{l}\text { Zhang and } \\
\text { colleagues }{ }^{\mathrm{E} 35}\end{array}$ & 2015 & Multivessel & $\begin{array}{r}\text { CABG vs PCI; } \\
\text { nonemergent }\end{array}$ & USA & Lifetime & NR & $\$ 11,575$ & 0.38 & $\$ 30,454$ \\
\hline $\begin{array}{l}\text { Yock and } \\
\text { colleagues }^{\mathrm{E} 36}\end{array}$ & 2003 & Multivessel & $\begin{array}{l}\text { CABG w/provisional } \\
\text { stent in follow-up } \\
\text { PCI vs initial PCI } \\
\text { w/provisional stent } \\
\text { vs CABG w/o stent } \\
\text { in follow-up PCI vs } \\
\text { CABG w/primary } \\
\text { stent in follow-up } \\
\text { PCI vs initial PCI } \\
\text { w/primary stent }\end{array}$ & USA & Lifetime & 2000 & $\begin{array}{l}\text { Initial PCI w/primary } \\
\text { stent vs CABG w/ } \\
\text { primary stent in } \\
\text { follow-up PCI: } \\
\text { \$3800; CABG w/ } \\
\text { primary stent in } \\
\text { follow-up PCI vs } \\
\text { CABG w/o stent in } \\
\text { follow-up PCI: } \\
\text { \$4100; CABG w/o } \\
\text { stent in follow-up } \\
\text { PCI vs initial PCI } \\
\text { w/provisional stent: } \\
\text { \$200; initial PCI w/ } \\
\text { provisional stent vs } \\
\text { CABG w/ } \\
\text { provisional stent in } \\
\text { follow-up PCI: } \\
\text { \$300 }\end{array}$ & $\begin{array}{l}\text { Initial PCI w/primary } \\
\text { stent vs CABG w/ } \\
\text { primary stent in } \\
\text { follow-up PCI: } \\
\text {-0.32; CABG w/ } \\
\text { primary stent in } \\
\text { follow-up PCI vs } \\
\text { CABG w/o stent in } \\
\text { follow-up PCI: } \\
\text { 0.02; CABG w/o } \\
\text { stent in follow-up } \\
\text { PCI vs initial PCI } \\
\text { w/provisional stent: } \\
0.34 \text {; Initial PCI w/ } \\
\text { provisional stent vs } \\
\text { CABG w/ } \\
\text { provisional stent in } \\
\text { follow-up PCI: } \\
\text {-0.35 }\end{array}$ & $\begin{array}{l}\text { Initial PCI w/primary } \\
\text { stent dominated by } \\
\text { CABG w/primary } \\
\text { stent in follow-up } \\
\text { PCI; CABG w/ } \\
\text { primary stent in } \\
\text { follow-up PCI vs } \\
\text { CABG w/o stent in } \\
\text { follow-up PCI: } \\
\text { \$205,000; CABG } \\
\text { w/o stent in follow- } \\
\text { up PCI vs initial } \\
\text { PCI w/provisional } \\
\text { stent: } \$ 588.24 ; \\
\text { Initial PCI w/ } \\
\text { provisional stent } \\
\text { dominated by } \\
\text { CABG w/ }\end{array}$ \\
\hline
\end{tabular}




\begin{tabular}{|c|c|c|c|c|c|c|c|c|c|}
\hline Author & Year & Population & Comparison & Country & Horizon & Cost year & $\Delta$ Costs & $\Delta$ Effectiveness $*$ & ICER* \\
\hline & & & & & & & & & $\begin{array}{l}\text { provisional stent in } \\
\text { follow-up PCI }\end{array}$ \\
\hline \multirow[t]{3}{*}{$\begin{array}{l}\text { Griffin and } \\
\text { colleagues }^{\mathrm{E} 37}\end{array}$} & 2007 & $\begin{array}{l}\text { Rated appropriate for } \\
\quad \text { CABG }\end{array}$ & CABG vs PCI vs MM & United Kingdom & $6 \mathrm{y}$ & $2003 / 2004$ & $\begin{array}{l}\text { CABG vs PCI: } £ 3230 \text {; } \\
\text { PCI vs MM: } £ 2640\end{array}$ & $\begin{array}{l}\text { CABG vs PCI: } 0.15 \\
\text { PCI vs MM: } 0.25\end{array}$ & $\begin{array}{l}\text { CABG vs PCI: } \\
£ 22,000 ; \text { PCI vs } \\
\text { MM: } £ 11,000\end{array}$ \\
\hline & & $\begin{array}{l}\text { Rated appropriate for } \\
\quad \text { PCI }\end{array}$ & CABG vs PCI vs MM & United Kingdom & $6 y$ & $2003 / 2004$ & $\begin{array}{l}\text { CABG vs PCI: } £ 4947 \text {; } \\
\text { PCI vs MM: } £ 2847\end{array}$ & $\begin{array}{l}\text { CABG vs PCI: }-0.07 \text {; } \\
\text { PCI vs MM: } 0.06\end{array}$ & $\begin{array}{l}\text { CABG dominated by } \\
\text { PCI; PCI vs MM: } \\
£ 47,000\end{array}$ \\
\hline & & $\begin{array}{l}\text { Rated appropriate for } \\
\text { CABG and PCI }\end{array}$ & CABG vs PCI vs MM & United Kingdom & $6 \mathrm{y}$ & $2003 / 2004$ & $\begin{array}{l}\text { CABG vs PCI: } £ 3820 \text {; } \\
\text { PCI vs MM: } £ 3435\end{array}$ & $\begin{array}{l}\text { CABG vs PCI: } 0.24 \\
\text { PCI vs MM: } 0.15\end{array}$ & $\begin{array}{l}\text { CABG vs MM: } \\
£ 19,000 ; \text { PCI } \\
\text { extendedly } \\
\text { dominated }\end{array}$ \\
\hline \multirow[t]{6}{*}{$\begin{array}{l}\text { Eisenstein and } \\
\text { colleagues }^{\mathrm{E} 38}\end{array}$} & 2009 & $\begin{array}{l}\text { Two-vessel with } \\
\text { normal-mild CKD }\end{array}$ & CABG vs PCI vs MM & USA & $3 \mathrm{y}$ & NR & $\begin{array}{l}\text { CABG vs PCI: } \$ 3079 \text {; } \\
\text { CABG vs MM: } \\
\text { \$9999; PCI vs MM: } \\
\$ 6891\end{array}$ & $\begin{array}{l}\text { CABG vs PCI: } \\
-0.050 ; \text { CABG vs } \\
\text { MM: } 0.038 ; \text { PCI vs } \\
\text { MM: } 0.058 \text { (LY) }\end{array}$ & $\begin{array}{l}\text { CABG vs PCI: CABG } \\
\text { dominated by PCI; } \\
\text { CABG vs MM: } \\
\text { \$332,506; PCI vs } \\
\text { MM: } \$ 140,129 \\
\text { (/LY) }\end{array}$ \\
\hline & & $\begin{array}{l}\text { Three-vessel with } \\
\text { normal-mild CKD }\end{array}$ & CABG vs PCI vs MM & USA & $3 y$ & NR & $\begin{array}{l}\text { CABG vs PCI: } \\
\text { - \$1561; CABG vs } \\
\text { MM: } \$ 5363 ; \text { PCI vs } \\
\text { MM: } \$ 5593\end{array}$ & $\begin{array}{l}\text { CABG vs PCI: } 0.098 \text {; } \\
\text { CABG vs MM: } \\
0.329 ; \text { PCI vs MM: } \\
0.162 \text { (LY) }\end{array}$ & $\begin{array}{l}\text { CABG vs PCI: CABG } \\
\text { dominates PCI; } \\
\text { CABG vs MM: } \\
\$ 20,299 ; \text { PCI vs } \\
\text { MM: } \$ 38,582 \text { (/LY) }\end{array}$ \\
\hline & & $\begin{array}{l}\text { Left main with } \\
\text { normal-mild CKD }\end{array}$ & CABG vs PCI vs MM & USA & $3 \mathrm{y}$ & NR & $\begin{array}{l}\text { CABG vs MM: } \\
\$ 15,491\end{array}$ & $\begin{array}{l}\text { CABG vs MM: } 0.599 \\
\text { (LY) }\end{array}$ & $\$ 28,588(/ \mathrm{LY})$ \\
\hline & & $\begin{array}{l}\text { Two-vessel with } \\
\text { moderate-severe } \\
\text { CKD }\end{array}$ & CABG vs PCI vs MM & USA & $3 y$ & NR & $\begin{array}{l}\text { CABG vs PCI: } \$ 8375 \text {; } \\
\text { CABG vs MM: } \\
\$ 4482 ; \text { PCI vs MM: } \\
-\$ 3375\end{array}$ & $\begin{array}{l}\text { CABG vs PCI: } 0.251 \text {; } \\
\text { CABG vs MM: } \\
0.360 ; \text { PCI vs MM: } \\
0.067 \text { (LY) }\end{array}$ & $\begin{array}{l}\text { CABG vs PCI: } \\
\text { \$36,593; CABG vs } \\
\text { MM: } \$ 15,661 ; \text { PCI } \\
\text { vs MM: PCI } \\
\text { dominates MM } \\
\text { (/LY) }\end{array}$ \\
\hline & & $\begin{array}{l}\text { Three-vessel with } \\
\text { moderate-severe } \\
\text { CKD }\end{array}$ & CABG vs PCI vs MM & USA & $3 \mathrm{y}$ & NR & $\begin{array}{l}\text { CABG vs PCI: } \\
\begin{array}{l}\$ 20,370 ; \text { CABG vs } \\
\text { MM: } \$ 23,264 ; \text { PCI } \\
\text { vs MM: }-\$ 787\end{array}\end{array}$ & $\begin{array}{l}\text { CABG vs PCI: } 0.407 \text {; } \\
\text { CABG vs MM: } \\
0.274 \text {; PCI vs MM: } \\
0.003 \text { (LY) }\end{array}$ & 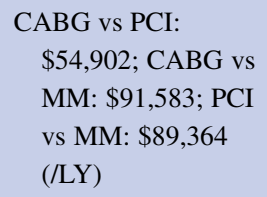 \\
\hline & & $\begin{array}{l}\text { Left main with } \\
\text { moderate-severe } \\
\text { CKD }\end{array}$ & CABG vs PCI vs MM & USA & $3 y$ & NR & CABG vs MM: $\$ 549$ & $\begin{array}{l}\text { CABG vs MM: } 0.729 \\
\text { (LY) }\end{array}$ & $\$ 3709(/ \mathrm{LY})$ \\
\hline
\end{tabular}


TABLE E4. Continued

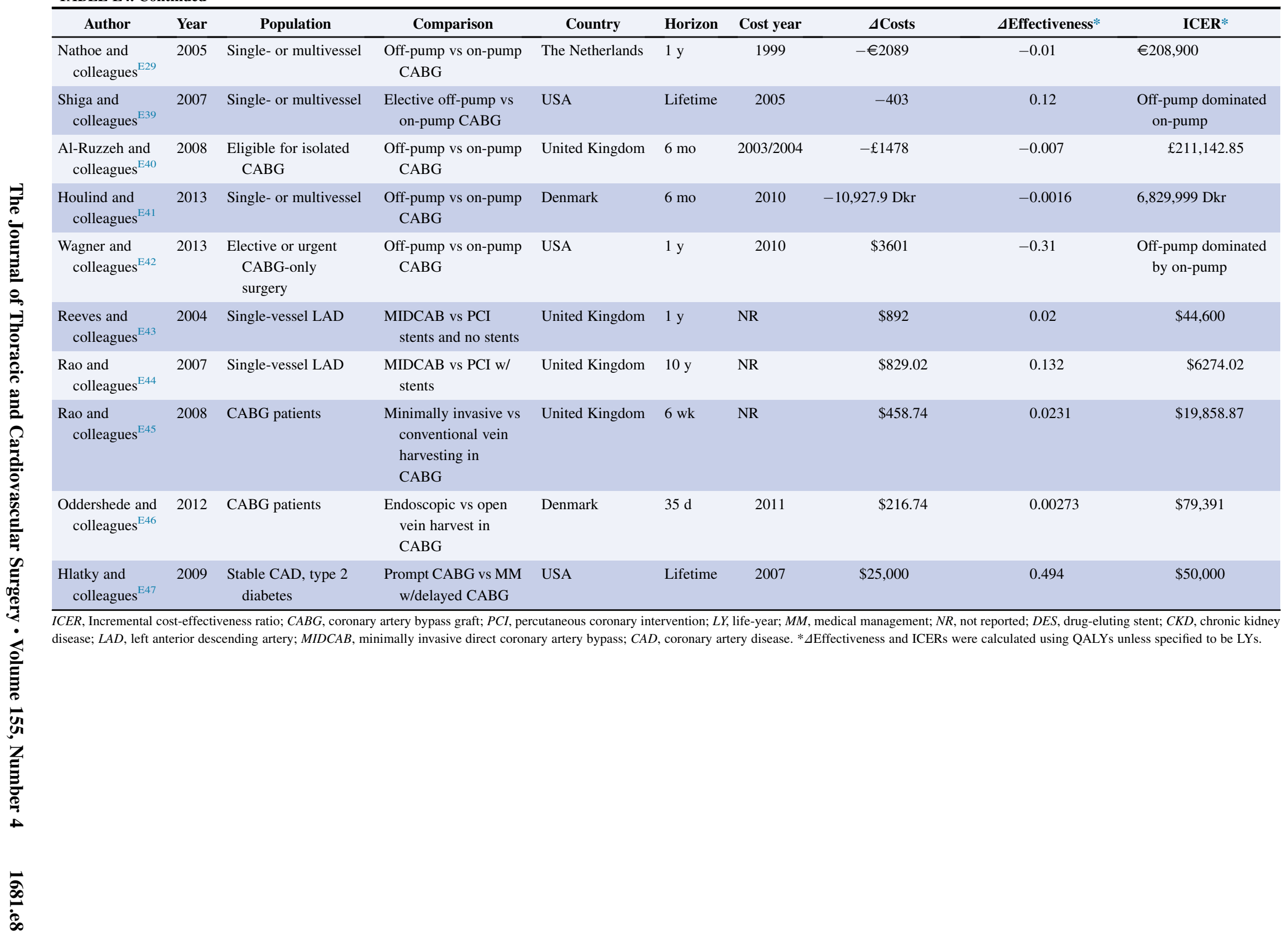


TABLE E5. Essential criteria of a useful model-based cost-effectiveness analysis

\begin{tabular}{|c|c|}
\hline Criterion* & Requirements \\
\hline Relevant decision problem & $\begin{array}{l}\text { The model addresses a medical decision problem with clear trade-offs between the potential benefits and harms } \\
\text { among the considered interventions }\end{array}$ \\
\hline Representative patient cohort & The model simulates a cohort representative of the target patient population or individual (eg, "average") patient \\
\hline Exhaustive comparisons & $\begin{array}{l}\text { All relevant, competing intervention strategies that can be considered for the decision problem are included in the } \\
\text { model }\end{array}$ \\
\hline Appropriate outcomes & $\begin{array}{l}\text { The cost and quality-of-life estimates are applicable to the (envisioned) clinical practice and analytic perspective } \\
\text { (eg, healthcare sector/societal), also the modeled fatal and nonfatal event rates are applicable to the target } \\
\text { population/patient }\end{array}$ \\
\hline Appropriate time horizon & $\begin{array}{l}\text { The model is capable to make projections over a sufficiently long time horizon to capture all relevant future costs } \\
\text { and beneficial and harmful health outcomes }\end{array}$ \\
\hline Transparent model & $\begin{array}{l}\text { The model and input parameters are well described, assumptions are clear and valid, and results on both } \\
\text { intermediate (eg, event rates, cumulative costs per event type) as primary model outcomes (aggregated cost and } \\
\text { effectiveness outcomes) are presented }\end{array}$ \\
\hline $\begin{array}{l}\text { Credible and plausible } \\
\text { model output }\end{array}$ & $\begin{array}{l}\text { The model generates output that matches with what can be expected from the current knowledge and plausible } \\
\text { explanations are provided if that is not the case }\end{array}$ \\
\hline $\begin{array}{l}\text { Internally valid and } \\
\text { generalizable predictions }\end{array}$ & $\begin{array}{l}\text { Predictions by the model are in agreement with observations from the underlying data source(s) and, especially } \\
\text { when the underlying data have limited sample size or have been modified, also with observations from external } \\
\text { independent data }\end{array}$ \\
\hline Experienced research team & The research team is experienced and team members have a track record of published cost-effectiveness analyses \\
\hline
\end{tabular}




\section{E-References}

E1. Gada H, Agarwal S, Marwick TH. Perspective on the cost-effectiveness of transapical aortic valve implantation in high-risk patients: outcomes of a decision-analytic model. Ann Cardiothorac Surg. 2012;1:145-55.

E2. Gada H, Kapadia SR, Tuzcu EM, Svensson LG, Marwick TH. Markov model for selection of aortic valve replacement versus transcatheter aortic valve implantation (without replacement) in high-risk patients. Am J Cardiol. 2012; 109:1326-33.

E3. Neyt M, Van Brabandt H, Devriese S, Van De Sande S. A cost-utility analysis of transcatheter aortic valve implantation in Belgium: focusing on a well-defined and identifiable population. BMJ Open. 2012;2:https://doi.org/10.1136/bmjopen-2012-001032.

E4. Reynolds MR, Magnuson EA, Wang K, Lei Y, Vilain K, Walczak J, et al. Costeffectiveness of transcatheter aortic valve replacement compared with standard care among inoperable patients with severe aortic stenosis: results from the Placement of Aortic Transcatheter Valves (PARTNER) Trial (Cohort B). Circulation. 2012;125:1102-9.

E5. Watt M, Mealing S, Eaton J, Piazza N, Moat N, Brasseur P, et al. Cost-effectiveness of transcatheter aortic valve replacement in patients ineligible for conventional aortic valve replacement. Heart. 2012;98:370-6.

E6. Doble B, Blackhouse G, Goeree R, Xie F. Cost-effectiveness of the Edwards SAPIEN transcatheter heart valve compared with standard management and surgical aortic valve replacement in patients with severe symptomatic aortic stenosis: a Canadian perspective. J Thorac Cardiovasc Surg. 2013;146: 52-60.e53.

E7. Hancock-Howard RL, Feindel CM, Rodes-Cabau J, Webb JG, Thompson AK, Banz K. Cost effectiveness of transcatheter aortic valve replacement compared to medical management in inoperable patients with severe aortic stenosis: $\mathrm{Ca}$ nadian analysis based on the partner trial cohort B findings. J Med Econ. 2013; 16:566-74.

E8. Murphy A, Fenwick E, Toff WD, Neilson MP, Berry C, Uren N, et al. Transcatheter aortic valve implantation for severe aortic stenosis: the cost-effectiveness case for inoperable patients in the United Kingdom. Int $J$ Technol Assess Health Care. 2013;29:12-9.

E9. Sehatzadeh S, Doble B, Xie F, Blackhouse G, Campbell K, Kaulback K, et al. Transcatheter aortic valve implantation (TAVI) for treatment of aortic valve stenosis: an evidence update. Ont Health Technol Assess Ser. 2013;13:1-40.

E10. Simons CT, Cipriano LE, Shah RU, Garber AM, Owens DK, Hlatky MA. Transcatheter aortic valve replacement in nonsurgical candidates with severe, symptomatic aortic stenosis: a cost-effectiveness analysis. Circ Cardiovasc Qual Outcomes. 2013;6:419-28.

E11. Brecker S, Mealing S, Padhiar A, Eaton J, Sculpher M, Busca R, et al Cost-utility of transcatheter aortic valve implantation for inoperable patients with severe aortic stenosis treated by medical management: a UK cost-utility analysis based on patient-level data from the advance study. Open Heart. 2014;1:e000155.

E12. Freeman PM, Protty MB, Aldalati O, Lacey A, King W, Anderson RA, et al. Severe symptomatic aortic stenosis: medical therapy and transcatheter aortic valve implantation (TAVI) - a real-world retrospective cohort analysis of outcomes and cost-effectiveness using national data. Open Heart. 2016;3: e000414.

E13. Reynolds MR, Magnuson EA, Lei Y, Wang K, Vilain K, Li H, et al. Cost-effectiveness of transcatheter aortic valve replacement compared with surgical aortic valve replacement in high-risk patients with severe aortic stenosis: results of the PARTNER (Placement of Aortic Transcatheter Valves) trial (Cohort A). J Am Coll Cardiol. 2012;60:2683-92.

E14. Fairbairn TA, Meads DM, Hulme C, Mather AN, Plein S, Blackman DJ, et al The cost-effectiveness of transcatheter aortic valve implantation versus surgical aortic valve replacement in patients with severe aortic stenosis at high operative risk. Heart. 2013;99:914-20.

E15. Reynolds MR, Lei Y, Wang K, Chinnakondepalli K, Vilain KA, Magnuson EA, et al. Cost-effectiveness of transcatheter aortic valve replacement with a self-expanding prosthesis versus surgical aortic valve replacement. J Am Coll Cardiol. 2016;67:29-38.

E16. Ribera A, Slof J, Andrea R, Falces C, Gutierrez E, Del Valle-Fernandez R, et al. Transfemoral transcatheter aortic valve replacement compared with surgical replacement in patients with severe aortic stenosis and comparable risk: cost-utility and its determinants. Int J Cardiol. 2015;182:321-8.

E17. Moore M, Barnhart GR, Chitwood WR Jr, Rizzo JA, Gunnarsson C, Palli SR, et al. The economic value of intuity in aortic valve replacement. J Med Econ. 2016;19:1011-7
E18. Mealing S, Feldman T, Eaton J, Singh M, Scott DA. EVEREST II high risk study based UK cost-effectiveness analysis of MitraClip ${ }^{\circledR}$ in patients with severe mitral regurgitation ineligible for conventional repair/replacemen surgery. J Med Econ. 2013;16:1317-26.

E19. Cameron HL, Bernard LM, Garmo VS, Hernandez JB, Asgar AW. A Canadian cost-effectiveness analysis of transcatheter mitral valve repair with the MitraClip system in high surgical risk patients with significant mitral regurgitation. J Med Econ. 2014;17:599-615.

E20. Armeni P, Boscolo PR, Tarricone R, Capodanno D, Maggioni AP, Grasso C et al. Real-world cost effectiveness of MitraClip combined with medical therapy versus medical therapy alone in patients with moderate or severe mitral regurgitation. Int J Cardiol. 2016;209:153-60.

E21. Asgar AW, Khairy P, Guertin MC, Cournoyer D, Ducharme A, Bonan R, et al. Clinical outcomes and economic impact of transcatheter mitral leaflet repair in heart failure patients. J Med Econ. 2016;20:1-9.

E22. Guerin P, Bourguignon S, Jamet N, Marque S. MitraClip therapy in mitral regurgitation: a Markov model for the cost-effectiveness of a new therapeutic option. J Med Econ. 2016;19:696-701.

E23. Lamotte M, Annemans L, Bridgewater B, Kendall S, Siebert M. A health economic evaluation of concomitant surgical ablation for atrial fibrillation. Eur J Cardiothorac Surg. 2007:32:702-10.

E24. Quenneville SP, Xie X, Brophy JM. The cost-effectiveness of maze procedures using ablation techniques at the time of mitral valve surgery. Int J Technol Assess Health Care. 2009;25:485-96.

E25. van Breugel NH, Bidar E, Essers BA, Nieman FH, Accord RE, Severens JL, et al. Cost-effectiveness of ablation surgery in patients with atrial fibrillation undergoing cardiac surgery. Interact Cardiovasc Thorac Surg. 2011;12:394-8.

E26. Anderson LH, Black EJ, Civello KC, Martinson MS, Kress DC Cost-effectiveness of the convergent procedure and catheter ablation for non-paroxysmal atrial fibrillation. J Med Econ. 2014;17:481-91.

E27. Eefting F, Nathoe H, van Dijk D, Jansen E, Lahpor J, Stella P, et al. Randomized comparison between stenting and off-pump bypass surgery in patients referred for angioplasty. Circulation. 2003;108:2870-6.

E28. Hlatky MA, Boothroyd DB, Melsop KA, Brooks MM, Mark DB, Pitt B, et al. Medical costs and quality of life 10 to 12 years after randomization to angioplasty or bypass surgery for multivessel coronary artery disease. Circulation. 2004;110:1960-6.

E29. Nathoe HM, van Dijk D, Jansen EW, Borst C, Grobbee DE, de Jaegere PP Off-pump coronary artery bypass surgery compared with stent implantation and on-pump bypass surgery: clinical outcome and cost-effectiveness at one year. Neth Heart J. 2005;13:259-68.

E30. Stroupe KT, Morrison DA, Hlatky MA, Barnett PG, Cao L, Lyttle C, et al. Cost-effectiveness of coronary artery bypass grafts versus percutaneous coronary intervention for revascularization of high-risk patients. Circulation. 2006;114:1251-7.

E31. Kastanioti C. Costs, clinical outcomes, and health-related quality of life of off-pump vs. on-pump coronary bypass surgery. Eur J Cardiovasc Nurs. 2007;6:54-9.

E32. Magnuson EA, Farkouh ME, Fuster V, Wang K, Vilain K, Li H, et al Cost-effectiveness of percutaneous coronary intervention with drug eluting stents versus bypass surgery for patients with diabetes mellitus and multivesse coronary artery disease: results from the FREEDOM trial. Circulation. 2013; 127:820-31.

E33. Cohen DJ, Osnabrugge RL, Magnuson EA, Wang K, Li H, Chinnakondepalli K, et al. Cost-effectiveness of percutaneous coronary intervention with drug-eluting stents versus bypass surgery for patients with 3-vessel or left main coronary artery disease: final results from the synergy between percutaneous coronary intervention with TAXUS and Cardiac Surgery (SYNTAX) trial. Circulation. 2014;130:1146-57.

E34. Javanbakht M, Bakhsh RY, Mashayekhi A, Ghaderi H, Sadeghi M. Coronary bypass surgery versus percutaneous coronary intervention: cost-effectiveness in Iran: a study in patients with multivessel coronary artery disease. Int J Technol Assess Health Care. 2014:30:366-73.

E35. Zhang Z, Kolm P, Grau-Sepulveda MV, Ponirakis A, O'Brien SM, Klein LW et al. Cost-effectiveness of revascularization strategies: the ASCERT study. $J$ Am Coll Cardiol. 2015;65:1-11.

E36. Yock CA, Boothroyd DB, Owens DK, Garber AM, Hlatky MA. Cost-effectiveness of bypass surgery versus stenting in patients with multivessel coronary artery disease. Am J Med. 2003;115:382-9.

E37. Griffin SC, Barber JA, Manca A, Sculpher MJ, Thompson SG, Buxton MJ, et al Cost effectiveness of clinically appropriate decisions on alternative treatment for angina pectoris: prospective observational study. BMJ. 2007;334:624. 
E38. Eisenstein EL, Sun JL, Anstrom KJ, DeLong ER, Szczech LA, Mark DB. Assessing the economic attractiveness of coronary artery revascularization in chronic kidney disease patients. J Med Syst. 2009;33:287-97.

E39. Shiga T, Apfel CC, Wajima Z, Ohe Y. Influence of intraoperative conversion from off-pump to on-pump coronary artery bypass grafting on costs and quality of life: a cost-effectiveness analysis. J Cardiothorac Vasc Anesth. 2007;21: 793-9.

E40. Al-Ruzzeh S, Epstein D, George S, Bustami M, Wray J, Ilsley C, et al. Economic evaluation of coronary artery bypass grafting surgery with and without cardiopulmonary bypass: cost-effectiveness and quality-adjusted life years in a randomized controlled trial. Artif Organs. 2008;32:891-7.

E41. Houlind K, Kjeldsen BJ, Madsen SN, Rasmussen BS, Holme SJ, Pallesen PA, et al. OPCAB surgery is cost-effective for elderly patients. Scand Cardiovasc J. 2013;47:185-92.

E42. Wagner TH, Hattler B, Bishawi M, Baltz JH, Collins JF, Quin JA, et al On-pump versus off-pump coronary artery bypass surgery: cost-effectiveness analysis alongside a multisite trial. Ann Thorac Surg. 2013;96:770-7.

E43. Reeves BC, Angelini GD, Bryan AJ, Taylor FC, Cripps T, Spyt TJ, et al. A multi-centre randomised controlled trial of minimally invasive direct coronary bypass grafting versus percutaneous transluminal coronary angioplasty with stenting for proximal stenosis of the left anterior descending coronary artery. Health Technol Assess. 2004;8:1-43.

E44. Rao C, Aziz O, Panesar SS, Jones C, Morris S, Darzi A, et al. Cost effectiveness analysis of minimally invasive internal thoracic artery bypass versus percutaneous revascularisation for isolated lesions of the left anterior descending artery. BMJ. 2007;334:621.

E45. Rao C, Aziz O, Deeba S, Chow A, Jones C, Ni Z, et al. Is minimally invasive harvesting of the great saphenous vein for coronary artery bypass surgery a cost-effective technique? J Thorac Cardiovasc Surg. 2008;135: 809-15.

E46. Oddershede L, Andreasen JJ, Brocki BC, Ehlers L. Economic evaluation of endoscopic versus open vein harvest for coronary artery bypass grafting. Ann Thorac Surg. 2012;93:1174-80.

E47. Hlatky MA, Boothroyd DB, Melsop KA, Kennedy L, Rihal C, Rogers WJ, et al Economic outcomes of treatment strategies for type 2 diabetes mellitus and coronary artery disease in the Bypass Angioplasty Revascularization Investigation 2 Diabetes Trial. Circulation. 2009;120:2550-8.

E48. Habbema JD, Wilt TJ, Etzioni R, Nelson HD, Schechter CB, Lawrence WF, et al. Models in the development of clinical practice guidelines. Ann Intern Med. 2014;161:812-8. 